\title{
An investigation of members of the tribe Ceramieae (Ceramiaceae, Rhodophyta) occurring on both the Mediterranean and Atlantic shores of Morocco
}

\author{
Mustapha Hassoun ${ }^{1, *}$, Michael J. Wynne ${ }^{2}$, Hanaa Moussa ${ }^{1}$, Ghizlane Salhi ${ }^{1}$, Hanaa \\ Zbakh $^{1}$, Hassane Riadi ${ }^{1}$ and Mohamed Kazzaz ${ }^{1}$ \\ ${ }^{1}$ Department of Biology, Faculty of Sciences, Abdelmalek Essaâdi University, 93000, BP. 2121, M'Hannech II, Tétouan, \\ Morocco \\ ${ }^{2}$ Department of Ecology and Evolutionary Biology and Herbarium, University of Michigan, Ann Arbor, MI 48109, USA
}

\begin{abstract}
A taxonomic study was recently carried out on species of the tribe Ceramieae (Ceramiaceae, Rhodophyta), following an evaluation of previously published records and on the basis of field and laboratory investigations. In Morocco, the tribe is represented by 5 genera: Ceramium ( 21 taxa at specific and infraspecific levels), Gayliella (3 species), and by one species each of Centroceras, Corallophila and Microcladia. Among these, there are five new records for Morocco: Centroceras gasparrinii, Ceramium botryocarpum, Ceramium cingulatum, Ceramium echionotum var. mediterraneum, and Gayliella taylorii. The report of C. echionotum var. mediterraneum from the Atlantic coast of Morocco is one of the rare records from outside the Mediterranean. Ceramium ciliatum var. robustum and Ceramium codii are recorded for the first time from the Atlantic coast of Morocco. Centroceras clavulatum is excluded from Moroccan flora having been misidentified for C. gasparrinii. This paper summarizes the taxonomic characters of these species with images and presents a key for their identification. This report is the first detailed record of the species of the tribe Ceramieae for Morocco. As a result, the total number of taxa at both specific and infraspecific levels accepted in the tribe Ceramieae for Morocco, under current taxonomy and nomenclature, is 27.
\end{abstract}

Key Words: Centroceras; Ceramieae; Ceramium; Corallophila; Gayliella; Microcladia; Morocco

\section{INTRODUCTION}

The red algal tribe Ceramieae C. Agardh ex Greville is a highly diverse group in terms of number of taxa at specific and infraspecific level (more than over 275 species according to Guiry and Guiry 2018). The tribe is represented in all marine habitats worldwide and is comprised of 12 genera separated on the basis of thallus habit; shape, number, and arrangement of cortical cells; and the developmental morphology and arrangement of the spermatangia, carposporophyte, and tetrasporangia (Hommersand 1963, Norris 1993, Cho et al. 2008). On the Moroccan coast, the tribe Ceramieae is represented by 5 genera: Ceramium Roth, Centroceras Kützing, Corallophila Weber-van Bosse, Gayliella T. O. Cho, L. J. McIvor et S. M. Boo, and Microcladia Greville.
(9) This is an Open Access article distributed under the terms of the Creative Commons Attribution Non-Commercial License (http://creativecommons.org/licenses/by-nc/3.0/) which permits unrestricted non-commercial use, distribution, and reproduction in any medium, provided the original work is properly cited.
Received April 29, 2018, Accepted August 29, 2018

*Corresponding Author

E-mail: hassoun.mustapha-etu@uae.ac.ma Tel: +212-678-99-74-09, Fax: +212-539-99-45-00 
The red algal genus Ceramium, containing more than half of all species of the tribe, is one of the largest red algal genera. It is common worldwide, with approximately 200 currently recognized species (Guiry and Guiry 2018). Representatives occur in nearly all eulittoral or shallow subtidal habitats (Maggs et al. 2002, De Barros-Barreto et al. 2006). Ceramium species are usually distinguished by such features as the arrangement of cortical filaments, the developmental morphology of tetrasporangia, and the shape of apices (Hommersand 1963, Itono 1972, Womersley 1978, Ballantine 1990). Thalli are completely or incompletely corticated and consist mostly of branched terete axes that are both prostrate and erect or erect only. This genus is easily recognizable because of periaxial cells forming rings at the nodes of the axial filaments that give rise to a strict pattern of acropetal and basipetal cortical filaments (Womersley 1978, Norris 1993, Millar 2002).

Cho et al. (2008) revised the Ceramium flaccidum complex using both morphological observations and molecular techniques and erected the new genus Gayliella, with five known species assigned to that genus. Gayliella differs from Ceramium in having three cortical initials per periaxial cell, of which the basipetal one is produced by horizontal division; alternate branching pattern; and unicellular rhizoids produced only from periaxial cells (Cho et al. 2008). Rhizoidal development is an important feature for distinguishing genera within this tribe. As in Gayliella, the rhizoids in Centroceras arise from periaxial cells only, and both genera share the character of three cortical filaments per periaxial cell (Hommersand 1963, Boo and Lee 1985, Norris 1993, Cho et al. 2008). However, Centroceras differs from most Ceramieae in that spermatangia are produced terminally on branched monosiphonous filaments that arise from the upper ends of the periaxial cells; rhizoids are cut off from periaxial cells only; cortical cells are angular and arranged in more or less straight rows parallel to the axis (Hommersand 1963). Development of the cortical filaments has been accepted as one of the important features for recognizing species in the genus Centroceras as well as in the tribe Ceramieae (Womersley 1978, Won et al. 2009).

Norris (1993) has transferred several species previously described as Centroceras to Corallophila. Both of these genera are characterized by aligned quadrangular to rectangular cortical cells covering the internodes. According to Weber-van Bosse (1923), Corallophila is similar to $\mathrm{Ce}$ ramium but it can be distinguished from Ceramium in having tetrasporangia in stichidia and from Reinboldiella
De Toni (a genus also belonging to the Ceramieae) in having rectangular cortical cells regularly arranged in longitudinal rows. However, Corallophila is distinguished from all genera of the tribe Ceramieae in having four cortical initials produced from each periaxial cell (Norris 1993, Abbott 1999, Cho et al. 2000). Corallophila is represented in Morocco by a single species.

Microcladia, the fifth genus of the tribe Ceramieae that occurs in Morocco (Benhissoune et al. 2003), is also represented in Morocco by a single species. The genus was established by Greville (1830) on the basis of Fucus glandulosus Solander ex Turner and distinguished from other genera of the tribe in having alternate-distichous branching, forwardly directed cortical filaments, and a continuous surface layer of relatively small, angular cells (Maggs and Hommersand 1993, Cho et al. 2008).

The present investigation summarizes the taxonomic characters of the species of the tribe Ceramieae that occur in Morocco. A key for their identification with illustrations is presented. Furthermore, the following five taxa are reported for the first time from Morocco: Centroceras gasparrinii (Meneghini) Kützing, Ceramium botryocarpum A. W. Griffiths ex Harvey, Ceramium cingulatum Weber-van Bosse, Ceramium echionotum var. mediterraneum Mazoyer, and Gayliella taylorii (E. Y. Dawson) T. O. Cho \& S. M. Boo.

\section{MATERIALS AND METHODS}

All specimens examined in this study were collected from different localities on the Atlantic and Mediterranean coasts of Morocco. The study was carried out in the period 2013-2017, in the upper subtidal (-0.5-1 m depth) and low intertidal of wave exposed rocky shores. Studies were carried out on samples preserved in $5 \%$ formalinseawater solution; sections were made by hand with a razor blade. When necessary, material was stained with $1 \%$ aqueous aniline blue and preserved on glass slides in Karo corn syrup. Voucher specimens were deposited in the Phycological Herbarium of the Phycology and Mycology Laboratory, Faculty of Sciences, Abdelmalek Essaâdi University, Tetouan, Morocco [= HTET] (Supplementary Table S1). Photomicrographs were taken with an Olympus camera XC50 coupled to Olympus Bx43 microscope (Olympus, Tokyo, Japan). For nomenclatural purposes the following taxonomic databases were used: Index Nominum Algarum (2018) and AlgaeBase (Guiry and Guiry 2018). 


\section{RESULTS AND DISCUSSION}

As mentioned above, on the Moroccan coast the tribe Ceramieae is represented by 5 genera reported since the earlier inventories of Kazzaz and Riadi (2000) followed by that of Benhissoune et al. (2003) reviewing the Ceramiales Oltmanns. They are Ceramium, Centroceras, Corallophila, Gayliella, and Microcladia. Recently, Hassoun et al. (2016) added two species of Ceramium, and five taxa are added in the present study. As a result, the total number of species and varieties in the tribe Ceramieae for Morocco, under current taxonomy and nomenclature, is 27.

The tribe Ceramieae is distinguished from other tribes in the Ceramiaceae by the cortication of all axes arising nodally, closing completely or leaving a clear gap over the internodes; elongate determinate ramuli absent; tetrasporangia from periaxial or cortical cells (Norris 1993, Womersley 1998).

Branching pattern, cortication of main axes, development of the cortical filaments, rhizoidal development and tetrasporangial features are important characteris- tics for distinguishing genera within this tribe (Table 1) (Hommersand 1963, Womersley 1978, Boo and Lee 1985, Boo and Yoon 1993, Norris 1993, Cho et al. 2008, Won et al. 2009).

\section{Ceramium}

Unlike the majority of the genera in the Ceramiales, no single reproductive feature is diagnostic of the genus Ceramium and, in fact within the genus itself, only tetrasporangial features are sometimes useful as taxonomic characters, the male and female reproductive structures being essentially uniform throughout.

There are 22 taxa of Ceramium that occur in Morocco; among these, three new records added in this study: $C e$ ramium botryocarpum, C. cingulatum, and C. echionotum var. mediterraneum.

\section{Key to species and varieties of Ceramium}

1a. Cortical bands with spines --.-- 2

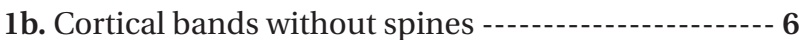

2a. Spines unicellular ---

Table 1. A comparison of genera of the tribe Ceramieae in Morocco

\begin{tabular}{|c|c|c|c|c|c|}
\hline & Ceramium & Centroceras & Corallophila & Gayliella & Microcladia \\
\hline Cortication & $\begin{array}{l}\text { Incompletely or } \\
\text { completely corti- } \\
\text { cated }\end{array}$ & $\begin{array}{l}\text { Completely corti- } \\
\text { cate }\end{array}$ & $\begin{array}{l}\text { Mostly or completely } \\
\text { corticated }\end{array}$ & $\begin{array}{l}\text { Incompletely corti- } \\
\text { cate }\end{array}$ & Completely corticate \\
\hline Branching pattern & $\begin{array}{l}\text { Pseudo-sub-dichot- } \\
\text { omous or irregu- } \\
\text { larly branched }\end{array}$ & $\begin{array}{l}\text { Usually dichoto- } \\
\text { mous }\end{array}$ & $\begin{array}{l}\text { Unbranched or } \\
\text { pseudodichoto- } \\
\text { mous }\end{array}$ & Alternate & Alternate-distichous \\
\hline $\begin{array}{l}\text { Growth of cortical } \\
\text { cells }\end{array}$ & $\begin{array}{l}\text { Acropetal and } \\
\text { basipetal }\end{array}$ & Mostly basipetal & Mostly basipetal & $\begin{array}{l}\text { Two acropetal and } \\
\text { one basipetal }\end{array}$ & Acropetal \\
\hline $\begin{array}{l}\text { Corticating } \\
\text { filaments or cells }\end{array}$ & 3-5 per periaxial cell & 3 per periaxial cell & 4 per periaxial cell & 3 per periaxial cell & 4 per periaxial cell \\
\hline Inner cortical cells & $\begin{array}{l}\text { Well-developed } \\
\text { along axis }\end{array}$ & Absent & Developed at nodes & Absent & $\begin{array}{l}\text { Well-developed } \\
\text { along axis }\end{array}$ \\
\hline Rhizoids & $\begin{array}{l}\text { Multicelullar cut off } \\
\text { from periaxial and } \\
\text { cortical cells }\end{array}$ & $\begin{array}{l}\text { Multicellular, pro- } \\
\text { duced from peri- } \\
\text { axial cells only }\end{array}$ & $\begin{array}{l}\text { Unicellular cut from } \\
\text { periaxial and inner } \\
\text { cortical cells }\end{array}$ & $\begin{array}{l}\text { Unicellular, elon- } \\
\text { gate, produced } \\
\text { from periaxial cells }\end{array}$ & $\begin{array}{l}\text { Multicellular, simple } \\
\text { or branched; pro- } \\
\text { duced from cortical } \\
\text { cells }\end{array}$ \\
\hline $\begin{array}{l}\text { Origin of } \\
\text { spermatangia }\end{array}$ & $\begin{array}{l}\text { From outer cortical } \\
\text { cells }\end{array}$ & $\begin{array}{l}\text { From monosi- } \\
\text { phonous filaments } \\
\text { borne on periaxial } \\
\text { cells }\end{array}$ & From cortical cells & From cortical cells & $\begin{array}{l}\text { From outer cortical } \\
\text { cells }\end{array}$ \\
\hline $\begin{array}{l}\text { Tetrasporangial } \\
\text { features }\end{array}$ & $\begin{array}{l}\text { From inner corti- } \\
\text { cal cells and / or } \\
\text { periaxial cells }\end{array}$ & From periaxial cells & $\begin{array}{l}\text { On stichidia or } \\
\text { regular branches, } \\
\text { from periaxial cells, } \\
\text { occasionally from } \\
\text { cortical cells }\end{array}$ & $\begin{array}{l}\text { From only periaxial } \\
\text { cells and fully cov- } \\
\text { ered with cortical } \\
\text { cells }\end{array}$ & $\begin{array}{l}\text { Arising initially from } \\
\text { periaxial cells and } \\
\text { then from cortical } \\
\text { cells or from corti- } \\
\text { cal cells only }\end{array}$ \\
\hline Cystocarps & $\begin{array}{l}\text { With involucral } \\
\text { branches }\end{array}$ & $\begin{array}{l}\text { With involucral } \\
\text { branches }\end{array}$ & $\begin{array}{l}\text { Without involucral } \\
\text { branches }\end{array}$ & $\begin{array}{l}\text { With involucral } \\
\text { branches }\end{array}$ & $\begin{array}{l}\text { With involucral } \\
\text { branches }\end{array}$ \\
\hline References & $\begin{array}{l}\text { Dixon (1960), Hom- } \\
\text { mersand (1963), } \\
\text { Boo and Lee (1994) }\end{array}$ & $\begin{array}{l}\text { Hommersand } \\
\text { (1963), Won et al. } \\
\text { (2009), Schneider } \\
\text { et al. (2015) }\end{array}$ & $\begin{array}{l}\text { Weber-van Bosse } \\
\text { (1923), Norris } \\
\text { (1993), Cho et al. } \\
(2000)\end{array}$ & Cho et al. (2008) & $\begin{array}{l}\text { Maggs and Hom- } \\
\text { mersand (1993) }\end{array}$ \\
\hline
\end{tabular}


2b. Spines multicellular ------- 4

3a. Main axes up to $300 \mu \mathrm{m}$ in diameter, incompletely or completely corticated; periaxial cells 8-9; branching pseudodichotomous every 8-14 node; tetrasporangia formed on adaxial side, 1-2 per node ---.-----.C. echionotum var. echionotum

3b. Main axes up to $150 \mu \mathrm{m}$ in diameter, incompletely corticated; periaxial cells 6-7; tetrasporangia immersed, formed in groups, in whorls of 1-5 per node --- C. echionotum var. mediterraneum

4a. Spines occur singly, 3-4-celled, conspicuous, basal cell of spines 0.7-1 longer than broad, slightly pigmented; main axes usually completely corticated; branching pseudodichotomous every 8-12 node -----

\section{C.gaditanum}

4b. Spines formed in whorls ------ 5

5a. Spines whorls of 5-6, 3-celled, conspicuous, basal cell of spines 1.5-3 long than broad, non-pigmented; periaxial cells 6-7; main axes incompletely corticated - Ciliatum var. ciliatum

5b. Spines whorls of 6-8; multicellular, up to 7(-8)-celled; periaxial cells 8-9; thalli are much branched, much more robust C. ciliatum var. robustum

6a. Axes and branches completely corticated or incompletely on the basal segments only ---.---.-- 7

6b. Axes and branches incompletely corticated throughout --.--- 12

7a. Branching regular, alternate / pseudo-dichotomous, every 4-9 node; periaxial cells 6-7; apices strongly inrolled; tetrasporangia formed in groups, in whorls at each node, immersed -----.-- C. pallidum

7b. Branching irregular ------------- 8

8a. Extensive prostrate axes present; adventitious branches abundant; periaxial cells 6-7, branching extremely irregular every 12-17 node --.---.---.---.-

C. botryocarpum

8b. Prostrate axes absent ------------- 9

9a. Cortication complete except in the basal segments; thalli with marked swelling after 3 or 4 basal segments; periaxial cells typically 9; without prostrate axes, rarely branched; solitary and straight apex; tetrasporangia whorled and immersed ----- C. giacconei

9b. Axes and branches completely corticated throughout -

10a. Apices strongly inrolled, periaxial cells 7-9; branching pseudodichotomous every 9-15 node; tetraspo-

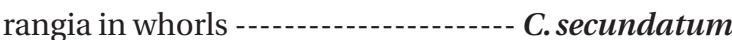

10b. Apices straight or slightly incurved ------------- 11

11a. Periaxial cells 6-7(-8); branching extremely irregular every 10-20 node -------- C. virgatum var. virgatum 11b. Periaxial cells typically 8 , rarely 9 ; branching approximately dichotomous every 8-13 node; branches differentiated in tendrils; pluricellular cortex --.--.---. C. virgatum var. implexocontortum

12a. Thallus rarely branched or never branched ------- 13

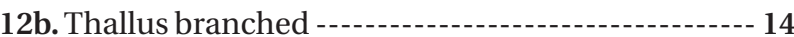

13a. Periaxial cells 4; extensive prostrate axis bearing short erect axes; apices are straight and unbranched; tetrasporangia unilaterally, one to two per node, strongly protruding, partially covered by cortical filaments ------.-- C. codii

13b. Periaxial cell 7-8; with prostrate and erect axes, unbranched; tetrasporangia whorled and protruding C. cingulatum

14a. Branching at small intervals, less than 7 segments - -

14b. Branching at longer intervals, more than 7 segments

5a. Periaxial cells typically 6 ; branching is regutarly ternate every 2nd node; apices straight to little incurved; adventitious branches absent; tetrasporangia formed singly and / or in group, developing in the plane of branching, completely naked --.---.---

C. callipterum

15b. Periaxial cells typically 8 ; branching at intervals of 4-7 segments ------ 16

16a. Branching regularly pseudodichotomous; little spaced nodes; apices tightly inrolled

C. siliquosum var. siliquosum

16b. Branching irregularly dichotomous; long spaced nodes; gland cells present, apices tightly inrolled with gland cells ---- C. siliquosum var. lophophorum

17a. Apices divergent and divaricate, straight or incurved but not strongly inrolled ---

17b. Apices strongly inrolled -------------- 19

18a. Periaxial cells 5-6; branching fairly regularly dichotomous every 6-12 node; many forked adventitious branches, inserted nearly perpendicularly; apices always divergent and divaricate (never incurved); tetrasporangia partly covered by cortical cells -----C. cornutum

18b. Periaxial cells typically 5 ; branching pseudodichotomous every 6-17 node; apices straight or incurved; tetrasporangia entirely naked, in a ring around the middle of each node; gland cells absent

\section{C. deslongchampsii}

19a. Tetrasporangia formed singly, rarely more than two per segment, on adaxial side of nodes; periaxial cells 6-7; tightly inrolled apices; branching pseudodichotomous every 8-13 node; gland cells present; ad- 
ventitious branches frequent -------- C. diaphanum

19b. Tetrasporangia formed in rows around nodes ---- 20

20a. Periaxial cells 9-10; regularly dichotomous at interval of 9-14 segments; apice incurved; extensive cortex in basipetal direction ---------- C. circinatum

20b. Periaxial cells 6-8; branching pseudodichotomous every 6-9 node; apices strongly inrolled to form forcipate tips; basipetal cells absent; pseudoperiaxial cells present; gland cells absent; tetrasporangia at most four, unilateral, abaxial, but have the tendency to form whorls

C. tenerrimum

According to Skage et al. (2005), three species groups are often recognized in Ceramium. One group can develop fully corticated internodes; species within this group are characterized by their ability to form cortication that completely covers the internodes. In Morocco, six fully corticated non-spinose taxa of Ceramium are currently recognized. The species of the second group are characterized by ecorticate internodes and represented by ten taxa in Morocco. The third group is characterized by cortical spines and is represented by five taxa in Morocco.

\section{Spinose species of Ceramium}

It is generally accepted that the presence or production of spines is a distinctive and defining specific character (Norris 1993, 2014, Womersley 1998). In Morocco, there are five taxa of Ceramium that have cortical bands with spines: C. echionotum J. Agardh var. echionotum, C. echionotum var. mediterraneum Mazoyer, C. ciliatum (J. Ellis) Ducluzeau var. ciliatum, C. ciliatum var. robustum (J. Agardh) Mazoyer, and C. gaditanum (Clemente) Cremades. Among these species, C. echionotum is the only one that has unicellular spines, developed near the apices on only the outer faces of nodes or in complete whorls of 5-7, angled in different directions (Fig. 1A-F) (Maggs and Hommersand 1993, Rodríguez-Prieto et al. 2013). The var. mediterraneum differs from the autonym in the following features: axes always incompletely corticated; periaxial cells 6-7 (incompletely or completely corticated; periaxial cells 8-9 in the var. echionotum); tetrasporangia formed in whorls of 1-5 per node (unilaterally, 1-2 in the autonym). In addition, the axes are up to $300 \mu \mathrm{m}$ in diameter in var. echionotum, whereas they are less than $150 \mu \mathrm{m}$ in var. mediterraneum (Fig. 1G-J) (Mazoyer 1938a, Feldmann-Mazoyer 1941, Secilla 2012). C. echionotum var. mediterraneum has not previously been recorded from Morocco, and the record of this variety in this study from the Atlantic coast of Morocco is one of the rare records from outside the Mediterranean.
Among species that have multicellular spines, C. gaditanum is mainly distinguished by its usually completely corticated axes (Fig. 2A \& B). Some authors (e.g., Maggs and Hommersand 1993, Secilla 2012) indicated that the spines in this species are typically one per segment and of 3-4 cells, but it is worth mentioning that C. gaditanum may develop several spines per segment, short, sparse and inconspicuous in the older parts of the thallus (Fig. $2 \mathrm{C}$ ), whereas at the apices and young portions, the spines are typically one per segment, pigmented and conspicuous (Fig. 2D).

Ceramium shuttleworthianum (Kützing) Rabenhorst, a species not occurring in Morocco but widely distributed in the north-eastern Atlantic Ocean (e.g., Spain, Portugal), also has multicellular spines formed usually one per segment, but occasionally a number of spines occur, forming a partial or complete whorl according to Dixon (1960). However, in C. shuttleworthianum the axes are incompletely corticated, and each of its nodes consists of 4 periaxial cells (5-6 periaxial cells in C. gaditanum). Moreover, $C$. gaditanum is the only species with multicellular spines that is completely corticated.

Ceramium ciliatum, one of the most commonly reported species in Morocco, is represented by two varieties, C. ciliatum var. ciliatum and C. ciliatum var. robustum (Gómez Garreta et al. 2001, Benhissoune et al. 2003). The var. ciliatum has 3-celled spines that are formed in whorls of 5-6 and has 6-7 periaxial cells, with pseudodichotomous branching from every 9-13 nodes and with strongly inrolled apices (Fig. 3A-E) (Maggs and Hommersand 1993, Secilla 2012, Rodríguez-Prieto et al. 2013). C. ciliatum var. robustum, however, has 8-9 periaxial cells and spines up to 8 cells, borne in whorls of 6-8; branching relatively dichotomous, fastigiate and pinnate; apices inrolled except in the tetrasporangial thalli where they are much less inrolled and almost straight (Fig. 3F-K) (Feldmann-Mazoyer 1941, Nakamura 1965, Itono 1972). The high number of cells of spines has been considered the main diagnostic character of var. robustum (Coppejans 1983, Wolf et al. 2011). Most records of var. robustum outside the Mediterranean report the presence of spines composed of 4 cells (e.g., Nakamura 1965, Itono 1972 from the Pacific Ocean), whereas the spines in the specimens reported from the Mediterranean Sea may be up to 8 cells (Feldmann-Mazoyer 1941). C. ciliatum var. robustum has been reported from the Mediterranean coast of Morocco (Gómez Garreta et al. 2001), and this is the first record of this variety from the Atlantic coast of Morocco. Our specimens have all diagnostic characters of var. robustum, and our observations confirm that the 

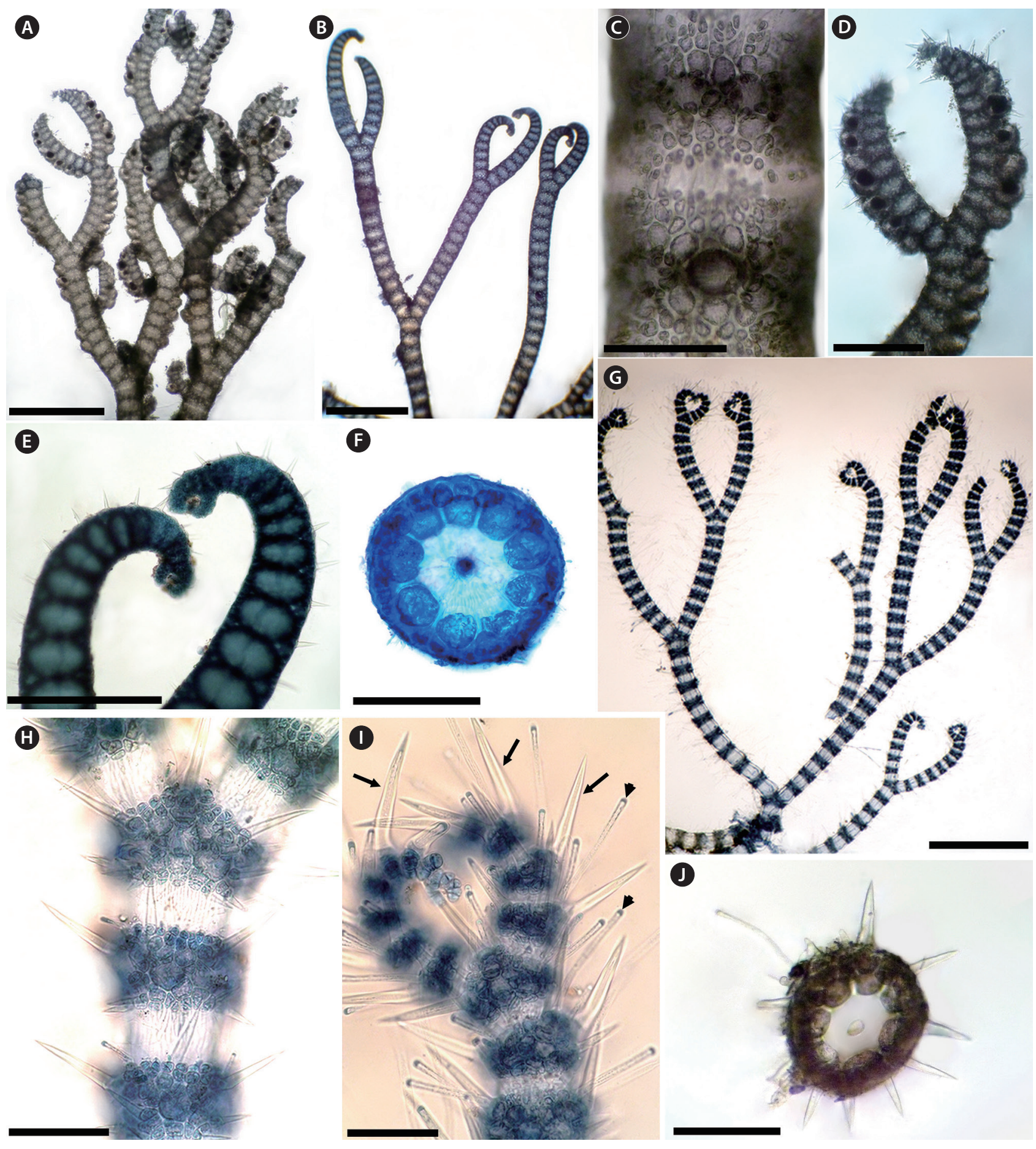

Fig. 1. (A-F) Ceramium echionotum var. echionotum. (A \& B) Habit showing completely or nearly completely corticated axes. (C) Close-up of the outer cortical cells in surface view. (D) Tetrasporangia on adaxial side of upper branches. (E) Inrolled apices. (F) Cross-section of a node showing nine periaxial cells. (G-J) C. echionotum var. mediterraneum. (G) Habit showing incompletely corticated axes. (H) Detail of cortical nodes. (I) Apices inrolled with unicellular spines (arrows) and hyaline hairs (arrowheads). (J) Cross-section of a node showing seven periaxial cells. Scale bars represent: A, B \& G, 1 mm; C-F, $200 \mu \mathrm{m} ; \mathrm{H}-\mathrm{J}, 100 \mu \mathrm{m}$. [Colour figure can be viewed at http://www.e-algae.org]. 

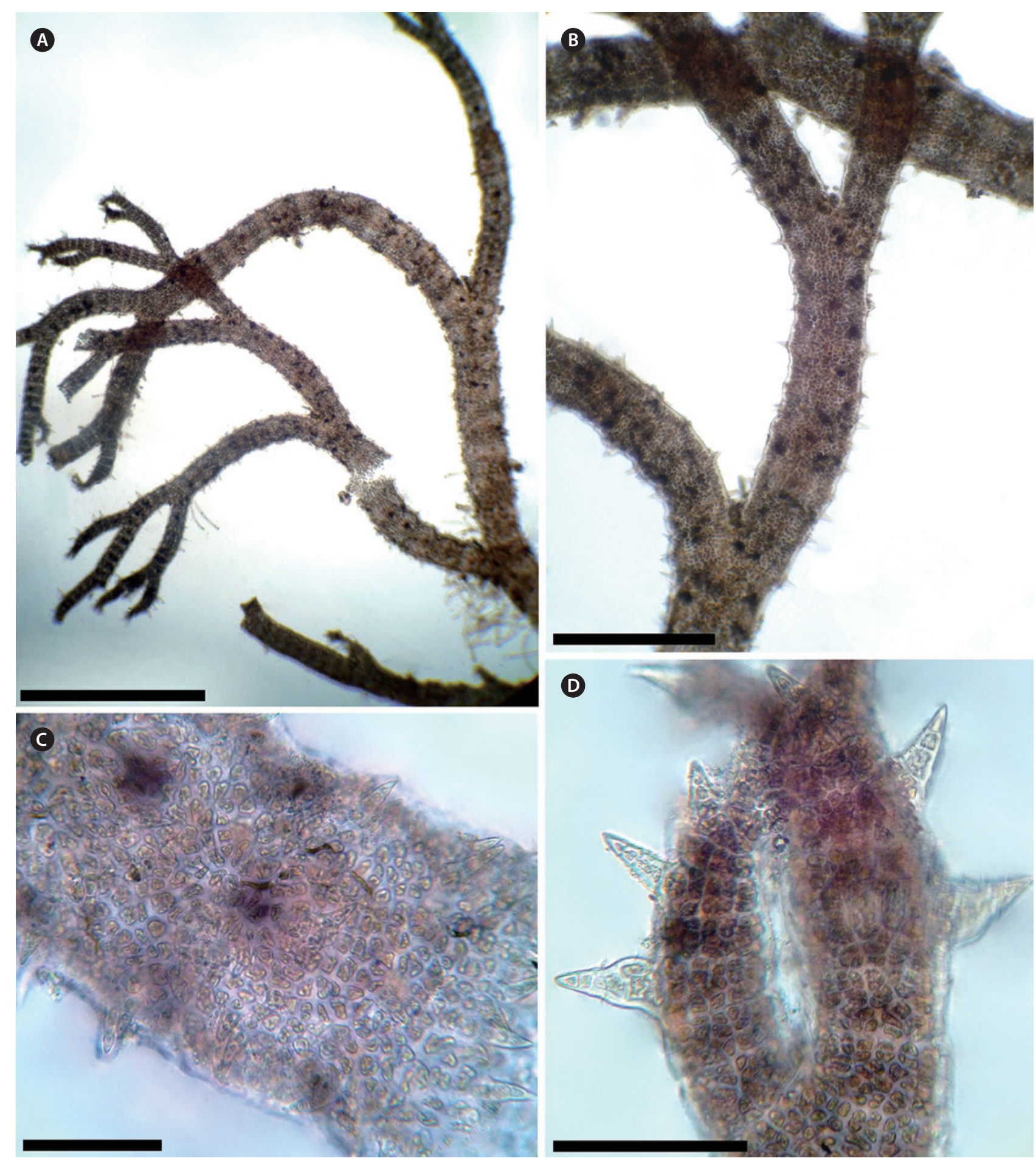

Fig. 2. Ceramium gaditanum. (A \& B) Habit of the thallus that is completely corticated. (C) Old part of the thallus showing sparse, short spines. (D) Apex with single multicellular spines. Scale bars represent: A, $1 \mathrm{~mm}$;, $400 \mu \mathrm{m} ; C$ \& D, $100 \mu \mathrm{m}$. [Colour figure can be viewed at http://www. e-algae.org]. 

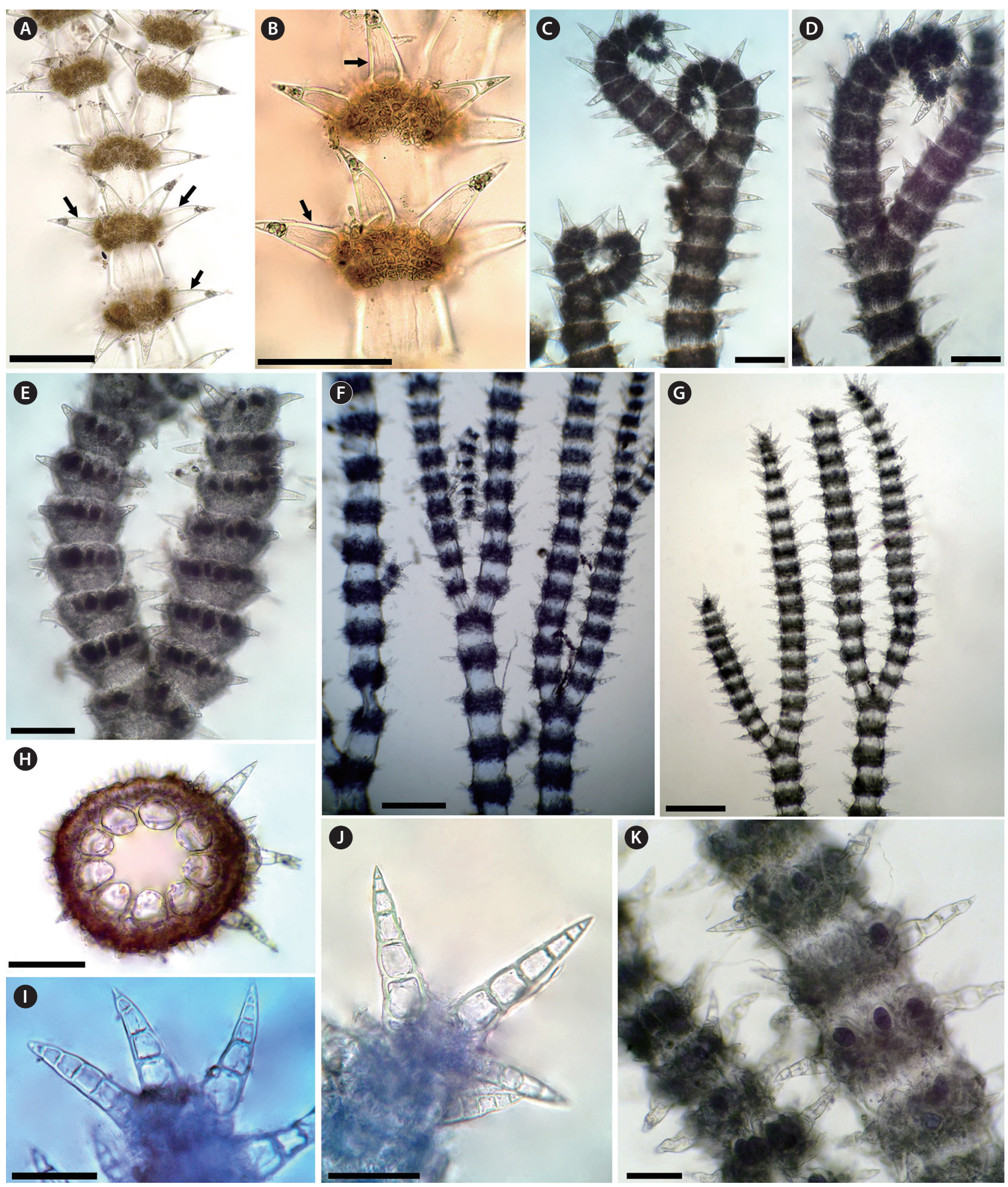

Fig. 3. (A-E) Ceramium ciliatum var. ciliatum. (A \& B) Detail of cortical nodes showing whorled spines, that are 3-celled. Arrows indicate the long basal cells (arrows). (C \& D) Inrolled apices with whorled spines. (E) Tetrasporangia arranged in whorls, immersed or partially protruding. (F-K) C. ciliatum var. robustum. (F \& G) Habit. (H) Cross-section of a node showing nine periaxial cells. (I \& J) Details of spines of up to 7-cells. (K) Partially protrudingtetrasporangia. Scale bars represent: A-G, $200 \mu \mathrm{m} ; \mathrm{H}-\mathrm{K}, 50 \mu \mathrm{m}$. [Colour figure can be viewed at http://www.e-algae.org]. 
multicellular spines of $C$. ciliatum var. robustum outside the Mediterranean may also up to 7(-8)-cells (Fig. 3I \& J).

Benhissoune et al. (2003) reported an allegedly spinose species of Ceramium from Morocco, namely, "Ceramium penicillatum Areschoug", which they pointed out to be a nom. illeg. That name was based on Gongroceras penicillatum Kützing (1849) and later transferred to Ceramium by Kylin (1907). That name, however, is a nomen. illeg., being a later homonym of $C$. penicillatum De Candolle in Lamarck \& De Candolle (1805). So this record for Morocco is discounted.

\section{Fully corticated Ceramium}

In Morocco, six fully corticated non-spinose taxa of Ceramium are currently recognized. These are Ceramium botryocarpum A. W. Griffiths ex Harvey, C. giacconei Cormaci \& G. Furnari, C. pallidum (Kützing) Maggs \& Hommersand, C. secundatum Lyngbye, C. virgatum Roth var. virgatum, C. virgatum var. implexocontortum (Solier) G. Furnari. Mostly, formerly confused under the illegitimate name Ceramium rubrum (Hudson) C. Agardh. $\mathrm{Ce}$ ramium pallidum is one among the four species recently added to Moroccan Ceramieae. Hassoun et al. (2016) described and discussed this species and its relationships with other species in the genus in detail. It is well marked by its regular interval of four to nine segments between branches and by its regular alternate branching pattern, becoming more regular at least five orders of branching, with dominant zigzag, with branch angles of $35-50^{\circ}$ and sometimes with ecorticate internode (Fig. 4A-E). A major specific character of C. pallidum is the type of the nodal cortication. C. pallidum possesses a cortication formed by cells of different sizes: a discontinuous outer layer of small cortical cells arranged in rosettes around inner cortical cells (Fig. 4C). Maggs et al. (2002) confirmed that the regular and short branching interval is of paramount importance in identifying this species, a character that we can confirm (Fig. 4A \& B). This species is absent in the Moroccan Mediterranean side and widely distributed throughout the Atlantic side, which leads us to conclude that this species has been misidentified as other similar common species such as $C$. virgatum because both species share some similarities. However, C. virgatum is clearly distinguished by its axes branching every 10 to 18 segments and by its extremely irregular branching pattern (Maggs and Hommersand 1993, Maggs et al. 2002, Rodríguez-Prieto et al. 2013). Furthermore, $C$. pallidum can be differentiated by its two acropetal corticating filaments and two basipetal that are produced from each corticating initial, while in C. virgatum each periaxial cells produces two cortical cells acropetally and two-three basipetally. In forming only two descending filaments from each periaxial cell it shows similarity to C. giacconei, which is otherwise quite distinct, chiefly by its habit.

Ceramium virgatum is the conserved type of the genus Ceramium (Greuter et al. 2000). It was cited by Agardh (1811) as a synonym of C. rubrum and later noted as possibly conspecific with C. nodulosum (Maggs and Hommersand 1993). Later, Maggs et al. (2002) suggested that the name C. virgatum Roth should be used for C. nodulosum (Lightfoot) Ducluzeau.

Ceramium virgatum var. implexocontortum a variety not found in this study, was reported in only one reference (González-García and Conde-Poyales 1994) and only on the Moroccan Mediterranean coast. Thus, its occurrence would require confirmation. It is characterized by a multicellular cortex and branches differentiated into tendrils, the number of periaxial cells is almost constantly 8; it is very exceptional to find 9 (Feldmann-Mazoyer 1941). According to Feldmann-Mazoyer (1941) the presence of these tendrils seems constant; it is a key feature used to separate this variety.

The fifth Moroccan completely corticated Ceramium species, C. secundatum, was previously recorded from very few localities (Mazoyer 1938a, González-García and Conde-Poyales 1994), and our records confirm and extend the distribution of this species in Morocco. It can be differentiated by its pseudodichotomous branching pattern at 9 to 15 branch intervals; strongly inrolled apices; tetrasporangia in whorls at each node on younger axes; adventitious branches present (Fig. 4F-I) (Maggs and Hommersand 1993, Maggs et al. 2002). C. secundatum is closely related to C. virgatum, and a monophyletic relationship was found between the two species in the British Isles by Maggs et al. (2002). However, the regular branching interval of 9-15 segments, showing a range of intervals within individual samples of 2-5 segments, and the numbers of periaxial cells that are up to 9 serve to discriminate C. secundatum from both C. virgatum and $C$. pallidum (Maggs et al. 2002, Hassoun et al. 2016).

As noted above, Ceramium secundatum is similar to $C$. virgatum and C. pallidum, but in forming two cells directed acropetally and two-three basipetally it is more similar to C. botryocarpum, a species reported for the first time from Morocco in this study. However, C. botryocarpum is distinguished in forming turfs due to development of extensive prostrate axes attached by a dense mass of multicellular rhizoids and by its cystocarps 

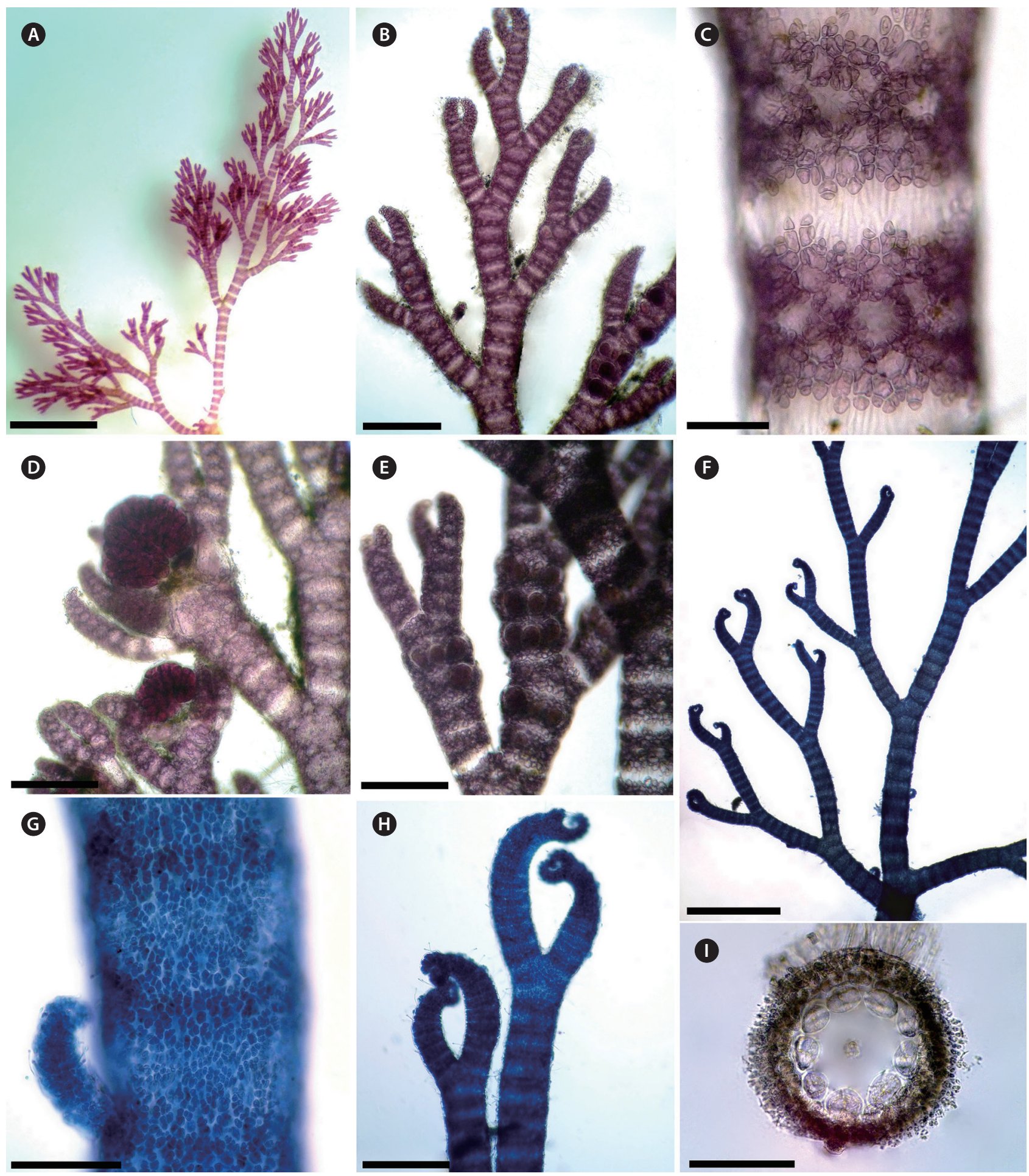

Fig. 4. (A-E) Ceramium pallidum. (A) Habit. (B) Distal parts of thallus with a dominant zigzag branching pattern. (C) Detail of cortical nodes showing small cortical cells arranged in rosettes around inner cortical cells. (D) Female thallus bearing cystocarps surrounded by involucral branchlets. (E) Tetrasporangial thallus. (F-I) C. secundatum. (F) Main axis showing branching pattern and interval of branching. (G) Cortex of fully corticated axis. (H) Inrolled apices. (I) Cross-section of a node showing nine periaxial cells. Scale bars represent: A, 2 mm; B, D, E \& H, 300 m; C, $100 \mu \mathrm{m} ; \mathrm{F}, 1 \mathrm{~mm} ; \mathrm{G} \& \mathrm{l}, 200 \mu \mathrm{m}$. [Colour figure can be viewed at http://www.e-algae.org]. 


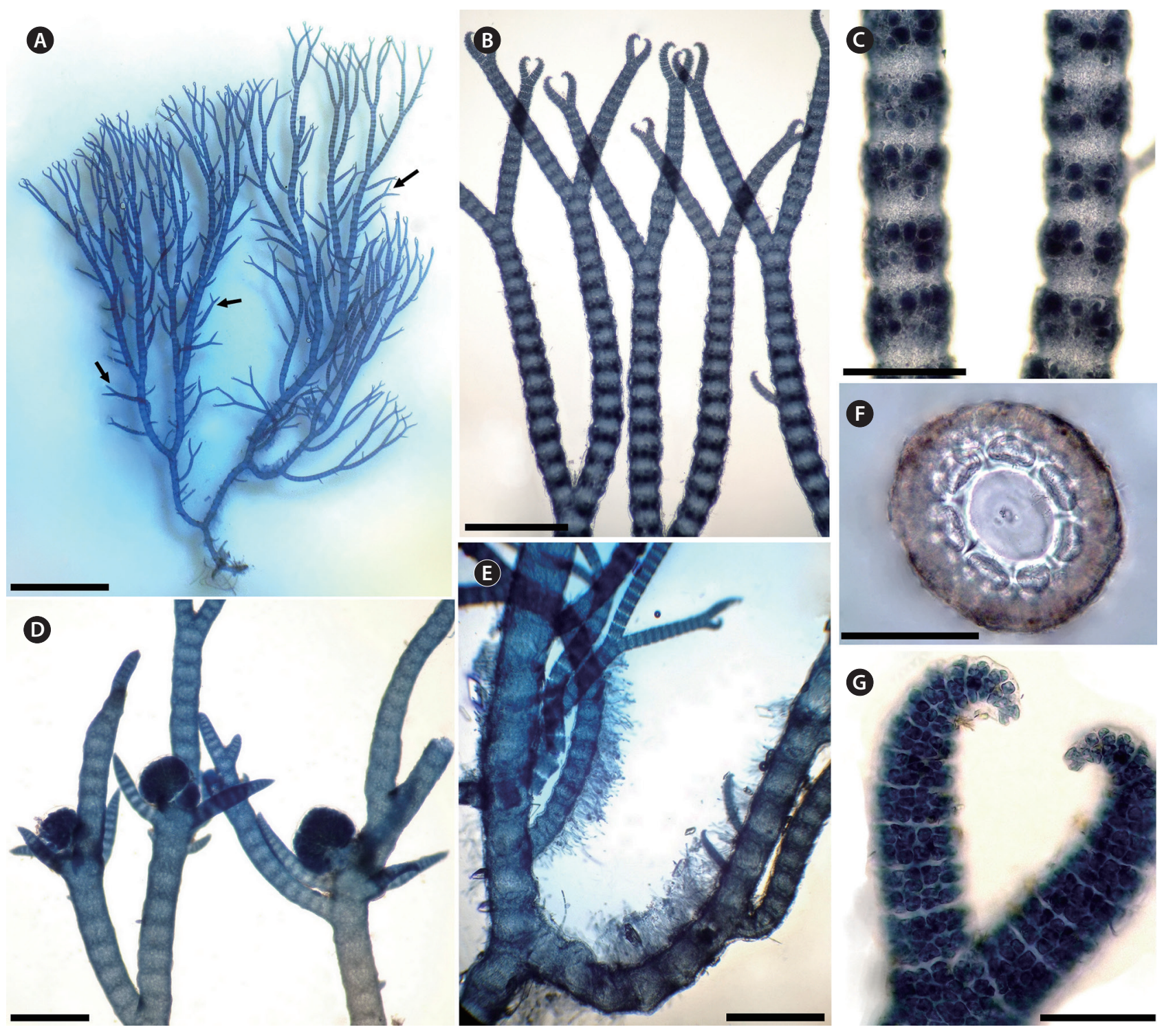

Fig. 5. Ceramium botryocarpum. (A) Habit of the thallus showing abundant adventitious branchlets (arrows). (B \& C) Axes with tetrasporangia arranged in whorls, immersed or partially protruding. (D) Thallus with cystocarps consisting of a single gonimolobe surrounded by involucral branchlets. (E) Prostrate axes with dense mass of multicellular rhizoids. (F) Cross-section of a node showing seven periaxial cells. (G) Detail of the apex. Scale bars represent: A, 5 mm, B \& E, 1 mm; C \& D, $400 \mu \mathrm{m} ; \mathrm{F} \& \mathrm{G}, 200 \mu \mathrm{m}$. [Colour figure can be viewed at http://www.e-algae.org].

consisting of a single (rarely two) globular gonimolobe (Maggs and Hommersand 1993, Secilla 2012). Our collections of C. botryocarpum (Fig. 5A-G) agree with previous descriptions and illustrations given by Maggs and Hommersand (1993) and Secilla (2012), in having prostrate axes attached by a dense mass of rhizoids, giving rise to erect axes; branching irregular or regularly dichotomous every 12-17 node; abundant adventitious branches; apices incurved to strongly incurved; periaxial cells 6-7; tetrasporangia immersed in the cortex, rarely semi- prominent, formed in wide bands in mature axes, 3 to 8 tetrasporangia at each node, and cystocarps consisting of a single gonimolobe. Ceramium botryocarpum is reported from the Atlantic coast of Morocco and not found on the Mediterranean side. It is widely distributed in the North Atlantic Ocean from Ireland to Portugal (Guiry and Guiry 2018). This is the first report of this species outside the northeastern Atlantic coast of Europe.

Ceramium giacconei (a species not found in this study) was described by Cormaci and Furnari (1991) to 

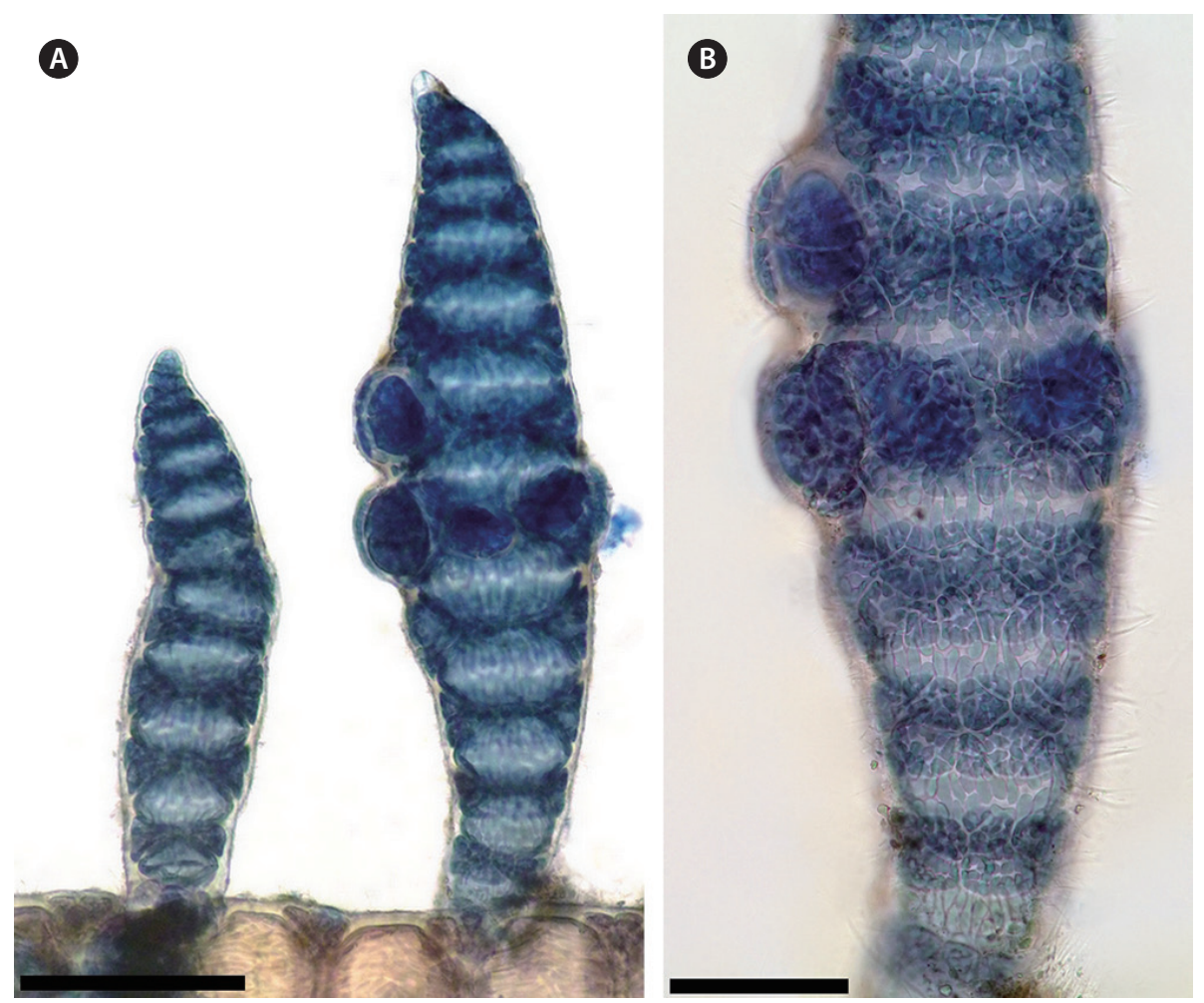

Fig. 6. Ceramium cingulatum. (A) Habit. (B) Detail of a thallus that is incompletely corticated with protruding tetrasporangia. Scale bars represent: $A, 400 \mu \mathrm{m} ; \mathrm{B}, 200 \mu \mathrm{m}$. [Colour figure can be viewed at http://www.e-algae.org].

accommodate the entity previously known in the Mediterranean as Ceramium cingulatum Weber-van Bosse. By comparing some Mediterranean specimens with the type material of $C$. cingulatum, Cormaci and Furnari described the Mediterranean material as C. giacconei sp. nov. Records of $C$. cingulatum from Mediterranean coast of Morocco by González-García and Conde-Poyales $(1991,1994)$ were considered as a misidentification for Ceramium giacconei by Gómez Garreta et al. (2001). In its original description, Cormaci and Furnari (1991) detailed the main features used to identify this species: erect thalli with the marked swelling after 3 or 4 basal segments, corticating filaments unequally developed from a cortical initial, cortication complete except on the basal segments (Cormaci and Furnari 1991, Cho et al. 2003). The combination of these characters makes it distinct from all other species of Moroccan Ceramium. Furthermore, Ceramium giacconei is also distinguished from C. cingulatum, a species reported for the first time from Morocco in this study, by its tetrasporangia being immersed in the cortex and thalli being completely erect (Cormaci and Furnari 1991, Cho et al. 2003), while C. cingulatum is characterized by its incompletely corticated thalli, creeping and erect without branching, and with protruding tetrasporangia (Fig. 6A\&B). Tetrasporophytic and sterile plants were collected in February to August; female and male plants were not found. This species was reported from the Atlantic coast of northern Morocco, commonly inhabiting upper sublittoral zone of rocky exposed shores, as an epiphyte on larger algae.

\section{Ceramium with ecorticate internodes}

Ten non-spinose species of Ceramium with ecorticate internodes are currently recognized from Morocco: $\mathrm{Ce}$ ramium callipterum Mazoyer, C. cingulatum Weber-van Bosse, C. circinatum (Kützing) J. Agardh, C. codii (H. Richards) Mazoyer, C. cornutum P. J. L. Dangeard, C. deslongchampsii Chauvin ex Duby, C. diaphanum (Lightfoot) Roth, C. siliquosum (Kützing) Maggs et Hommersand var. siliquosum, C. siliquosum var. lophophorum (Feldmann-Mazoyer) Serio, and C. tenerrimum (G. Martens) Okamura (see Gómez Garreta et al. 2001, Benhissoune et al. 2003, Hassoun et al. 2016). C. cornutum, one of the Ceramium species that was recently added to Morocco by Hassoun et al. (2016), is a species described from Cap 
Vert. This species was collected from the Moroccan Atlantic coast. It is well marked by the apices being always divaricate, never incurved, and by the many forked adventitious branches, with the lateral branches inserted nearly perpendicularly (Fig. 7A-E). These two characters make it a very distinct species, not just from Moroccan Ceramium but from all other species of the genus.

Tetrasporophytic plants of C. cornutum are observed from February to August, cystocarpic plants from May to September. This species has been previously reported in the warm temperate and tropical parts of the eastern Atlantic Ocean with vegetative and tetrasporophytic thalli. Now, both tetrasporophytes and female gametophytes have been found.

Ceramium diaphanum (Lightfoot) Roth is well known, but it appears that literature records of this species from Morocco are based upon taxonomic confusion. The only citations referred to $C$. diaphanum are those under $C$. nodosum sensu Griffiths et Harvey and C. tenuissimum (Roth) J. Agardh, nom. illeg. (Maggs and Hommersand 1993). It has been recorded several times as C. tenuissimum (Roth) Areschoug nom. illeg., and as C. nodosum sensu Griffiths et Harvey. But it has probably also been confused with C. siliquosum (Kützing) Maggs et Hommersand as pointed out by Benhissoune et al. (2003) in that $C$. siliquosum is one of the names available for $C$. $d i$ aphanum sensu Harvey, and literature records of C. siliquosum are difficult to assess owing to taxonomic confusion. However, this takes into consideration that these records were probably based upon Harvey's specimens and illustrations (C. diaphanum sensu Harvey) and on Feldmann-Mazoyer's (1941) concept of $C$. diaphanum var. diaphanum.

At the macromorphological level, these two species ( $C$. diaphanum and C. siliquosum) share some similarities, mainly in the extent of cortical development, each periaxial cell gives rise to two cells directed acropetally and two basipetally, in the branching pattern: pseudodichotomous, but at intervals of 4-7 segments in C. siliquosum (Fig. 7F \& G), 8-13 segments in C. diaphanum; and somewhat in the curvature of the apices, they are mostly tightly inrolled (Maggs and Hommersand 1993). However, C. siliquosum has tetrasporangia located in whorls protruding from the upper half of the nodes and entirely covered by ascending cortical filaments, which contrasts with $C$. diaphanum, in which tetrasporangia are scattered singly or in small groups on the adaxial side of the node and partially covered. Furthermore, conspicuous gland cells are present in C. diaphanum but absent in C. siliquosum.

Two varieties of Cermium siliquosum are known to oc- cur in Morocco: C. siliquosum var. siliquosum, occurs on the Mediterranean and Atlantic shores of Morocco and C. siliquosum var. lophophorum was previously reported only from the Mediterranean shores by González-García and Conde-Poyales (1994). The latter, not found in this study, differs from the autonym in having inrolled apices with conspicuous gland cells, developed on their outer side; and irregularly dichotomous branching (FeldmannMazoyer 1941).

Among species cited bibliographically from Morocco by only a single reference are those of C. deslongchampsii by Mazoyer (1938a) and of C. codii by González-García and Conde-Poyales (1994). The latter species was first described by Richards (1901) for a small alga that was collected in Bermuda as an epiphyte on Codium, and it has been recognized as being widely distributed in warm temperate and tropical areas. Among the 14 described creeping Ceramium species characterized by a predominantly prostrate habit, $C$. codii is the only one that occurs in Morocco.

Within the genus, three cortical initials per periaxial cell have been reported in Ceramium reptans $\mathrm{T}$. O. Cho et Fredericq, C. periconicum and C. codii (Cho and Riosmena-Rodriguez 2008). However, C. codii is recognized by a combination of the following characters: prostrate axes producing unbranched, upright axes dorsally, four periaxial cells per axial cell, three cortical cells cut off per periaxial cell with the basipetal cortical cell cut off horizontally on the prostrate axis, and 1-2 tetrahedrally divided tetrasporangia produced per periaxial cell (Cho and Fredericq 2006, N'Yeurt and Payri 2010). Likewise, this minute species of Ceramium is easily distinguished by its minimal nodal cortication, sparse to simple branching, and its long internodes (Fig. 7H \& I).

Ceramium deslongchampsii, a species not found in this study, also has prostrate axes, but not predominantly so, and bears numerous densely tufted and densely branched erect axes. These features are in contrast to $C$. codii, which has unbranched erect axes and apices (Itono 1972, Maggs and Hommersand 1993, Cho and Fredericq 2006). C. deslongchampii also differs from C. codii in that the tetrasporangia are formed in groups in a row around nodes (one or two tetrasporangia develop from a single periaxial cell in C. codii), by 5-6 periaxial cells per axial cell, each periaxial cell produces two acropetal and two basipetal cortical filament (only 4 in C. codii and two acropetal, one basipetal cortical filament). C. cingulatum, a species reported in Morocco (the Atlantic coast) for the first time in this study, also has prostrate axes, but it is more closely related to $C$. giacconei than any other 

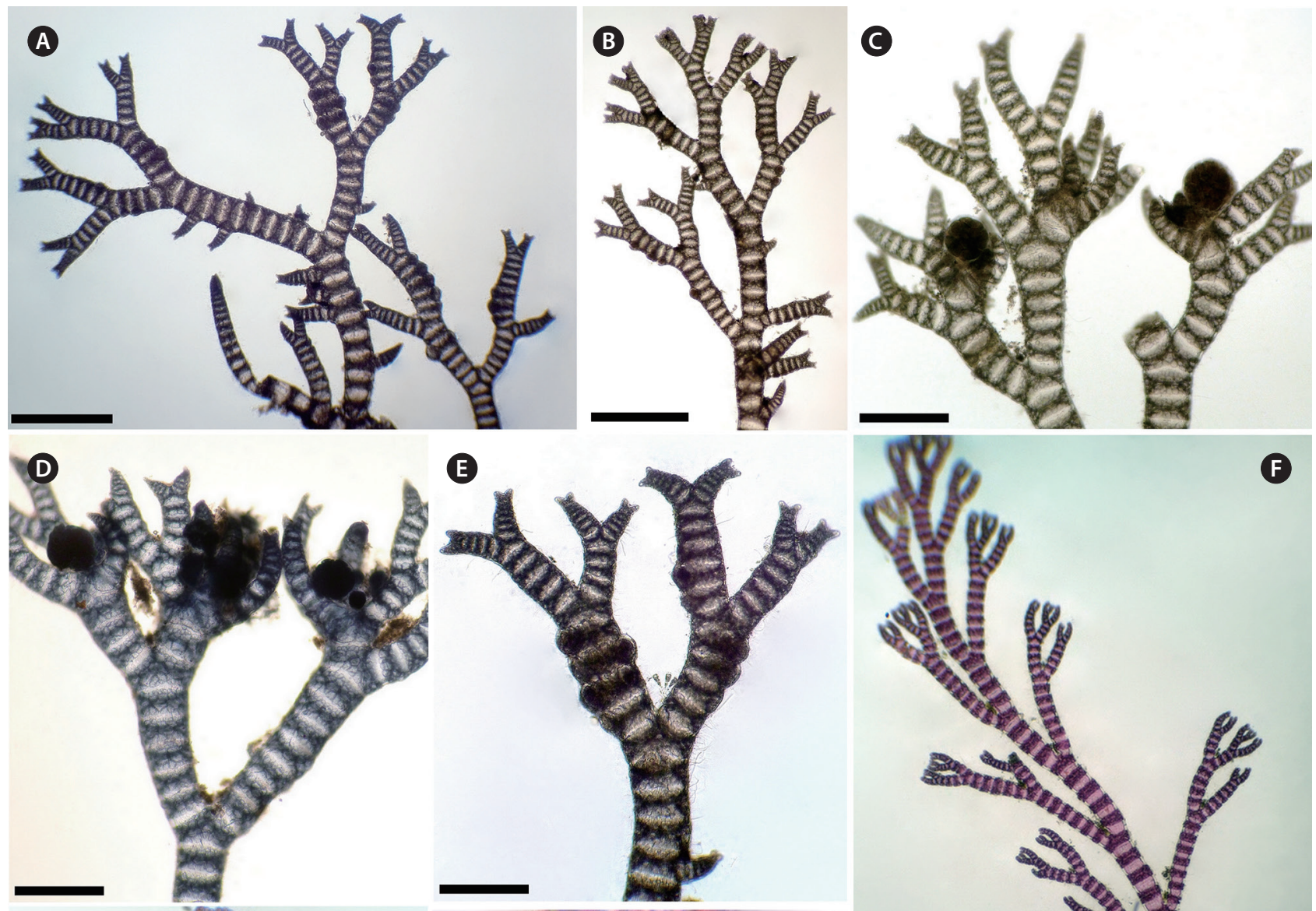

\section{(E)}

(
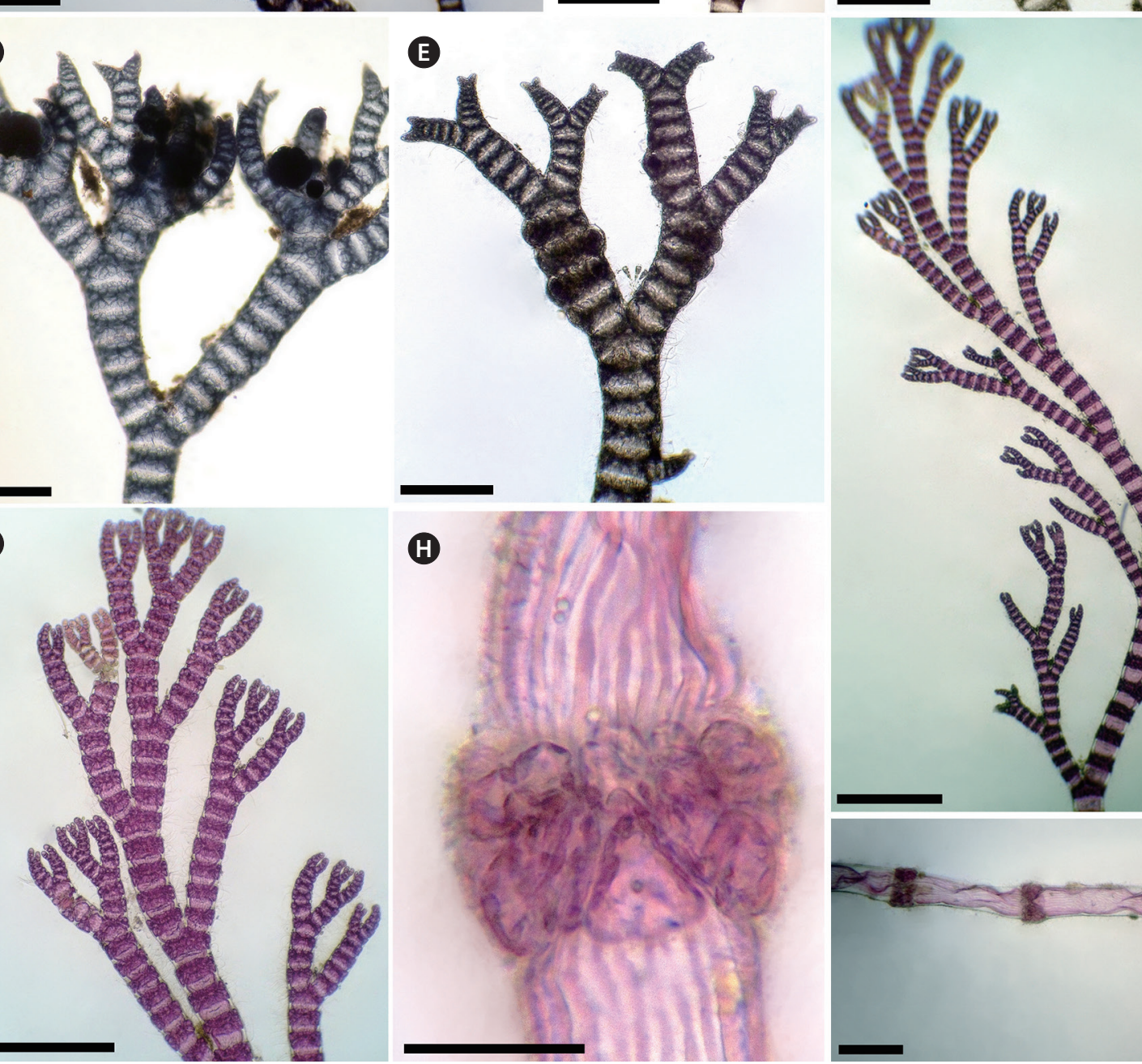

F

$\boldsymbol{H}$
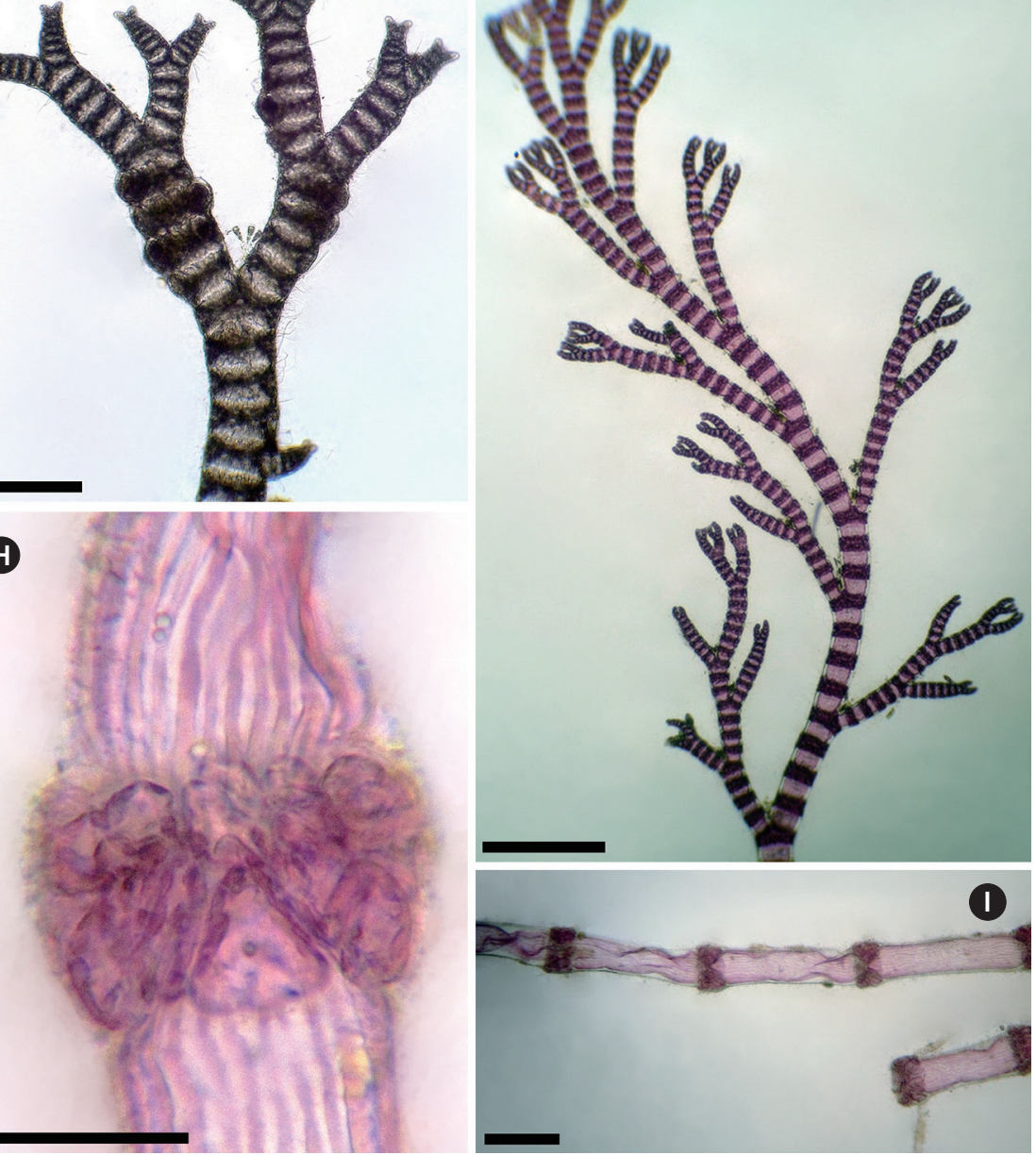

Fig. 7. (A-E) Ceramium cornutum. (A \& B) Habit. (C \& D) Female thallus bearing cystocarps surrounded by involucral branchlets. (E) Upper part of thallus showing tetrasporangial rows and divaricate and divergent apices. (F \& $G) C$. siliquosum var. siliquosum. (F) Habit. (G) Thallus showing interval of branching. (H \& I) C. codii. (H) Detail of nodal cortication. (I) Axis with long internodes. Scale bars represent: A, B, F \& G, 1 mm; C-E, 400 $\mu \mathrm{m} ; \mathrm{H}, 30 \mu \mathrm{m} ; \mathrm{l}, 100 \mu \mathrm{m}$. [Colour figure can be viewed at http://www.e-algae.org]. 
species in the genus as discussed above.

It is interesting that Ceramium codii, one of the most commonly reported species in the eastern North Atlantic Ocean and the Mediterranean Sea, was cited in only one reference from Morocco (Mediterranean side). Thalli up to $4 \mathrm{~mm}$ in length were sometimes found, but a length of 0.3-0.7 $\mathrm{mm}$ was the typical size. The species is likely to be simply overlooked when collecting or sorting due to its small size. On the other hand, $C$. codii may not be as widespread a species as is widely reported in the literature, and it may comprise several distinct entities (Coppejans 1977, Cho and Fredericq 2006). This is the first record of this species from the Moroccan Atlantic coast.

As mentioned above, 21 taxa of Ceramium at specific and infraspecific level are known from Morocco. Of these, only one, C. tenerrimum, has cortication produced acropetally only (Fig. 8A-D). It is a key feature in the identification of this species because some of the other characters appear to be variable. For example, De Barros-Barreto et al. (2006), Nunes et al. (2008), and Serio et al. (2011) characterized this species with eight to nine periaxial cells. However, a periaxial cell number of nine was not reported for C. tenerrimum by Lagan and Trono (2017), but according to those authors it varied between 6-8 periaxial cells. In addition, the periaxial cell number varied within individual thalli and axes studied by Simons (1966). The number reported by Rodríguez-Prieto et al. (2013) varied between 6-7, never eight or nine. However, we note that this species appeared to be particularly variable and that its morphological limits, particularly, reduced the value of the number of periaxial cells to distinguish species.

In contrast to $C$. tenerrimum, the number of periaxial cells in C. circinatum is one of the important distinguishing features of this species. This is the only species among Ceramium occurring in Morocco that has nine to ten periaxial cells (Fig. $8 \mathrm{H}$ ). Moreover, $\mathrm{C}$. circinatum has a different cortication to that of $C$. tenerrimum, that is, both acropetal and basipetal in the former species and only acropetal in the latter. Generally, C. circinatum develops an extensive cortex in the basipetal direction (Fig. 8E-G) (Simons 1966, Coppejans and Boudouresque 1981, Sansón 1994). Moreover, the intervals of branching of the main axes in C. circinatum (every 9-14 node) are greater than in C. tenerrimum (every 6-9 node) (Feldmann-Mazoyer 1941, De Barros-Barreto et al. 2006). Both of these species occur on the two shores of Morocco, Atlantic and Mediterranean.

Ceramium callipterum is the species that has very small intervals of branching of the main axes, at intervals of only 2 segments. This is a key feature separating this species (Mazoyer 1938b, Anderson and Stegenga 1989). This species, which has a type locality of Mazagan (Al Kadoda), Morocco (Silva et al. 1996), but not found during this study, has a limited distribution in the northeastern Atlantic Ocean (Guiry and Guiry 2018). The littleknown species Ceramium callipterum is recognized by the following characteristics: main axes with a regular alternate branching, at every second segment, giving the plants a plumose appearance, apices that are straight to slightly incurved, 6 periaxial cells per node, exserted and prominent tetrasporangia, formed singly or in groups, sometimes forming small clusters (see Mazoyer 1938b, p. 17, Fig. 2)

As above mentioned, five taxa of this genus reported previously from Morocco were not found during the present study: C. callipterum, C. giacconei, C. deslongchampsii, C. virgatum var. implexocontortum, and C. siliquosum var. lophophorum.

\section{Gayliella}

The genus Gayliella was erected by Cho et al. (2008) to accommodate the Ceramium flaccidum complex using molecular techniques and morphological analyses. The genus is clearly distinguished by the production of three cortical initials per periaxial cell, of which the third is directed basipetally and divides horizontally (Fig. 9F \& G). All species in the genus are incompletely corticated and have alternate branching (Fig. 10A-D); unicellular elongate rhizoids are produced from periaxial cells (Fig. 9I \& J).

Three Gayliella-related taxa were reported from Morocco with little morphological information: Ceramium flaccidum (Harvey ex Kützing) Ardissone, C. gracillimum (Kützing) Griffiths et Harvey, and C. gracillimum var. byssoideum Mazoyer (Dangeard 1949, Benhissoune et al. 2003). In the present study, G. taylorii (E. Y. Dawson) T. O. Cho et S. M. Boo is newly added from Morocco. In addition, the three reported taxa have been found to represent Gayliella flaccida and Gayliella mazoyerae T. O. Cho, Fredericq et Hommersand.

\section{Key to species of Moroccan Gayliella}

1a. Periaxial cells number 4 ; cortex $<70 \mu \mathrm{m}$ long; basipetal cells one row; branching intervals $4-5$ on main axes, 4-6 on lateral axes; gland cells inconspicuous, rarely observed; tetrasporangia whorled, tetrahedrally divided ------ G. mazoyerae

lb. Periaxial cells number $>4$, basipetal cells $2-3$ rows ---- 


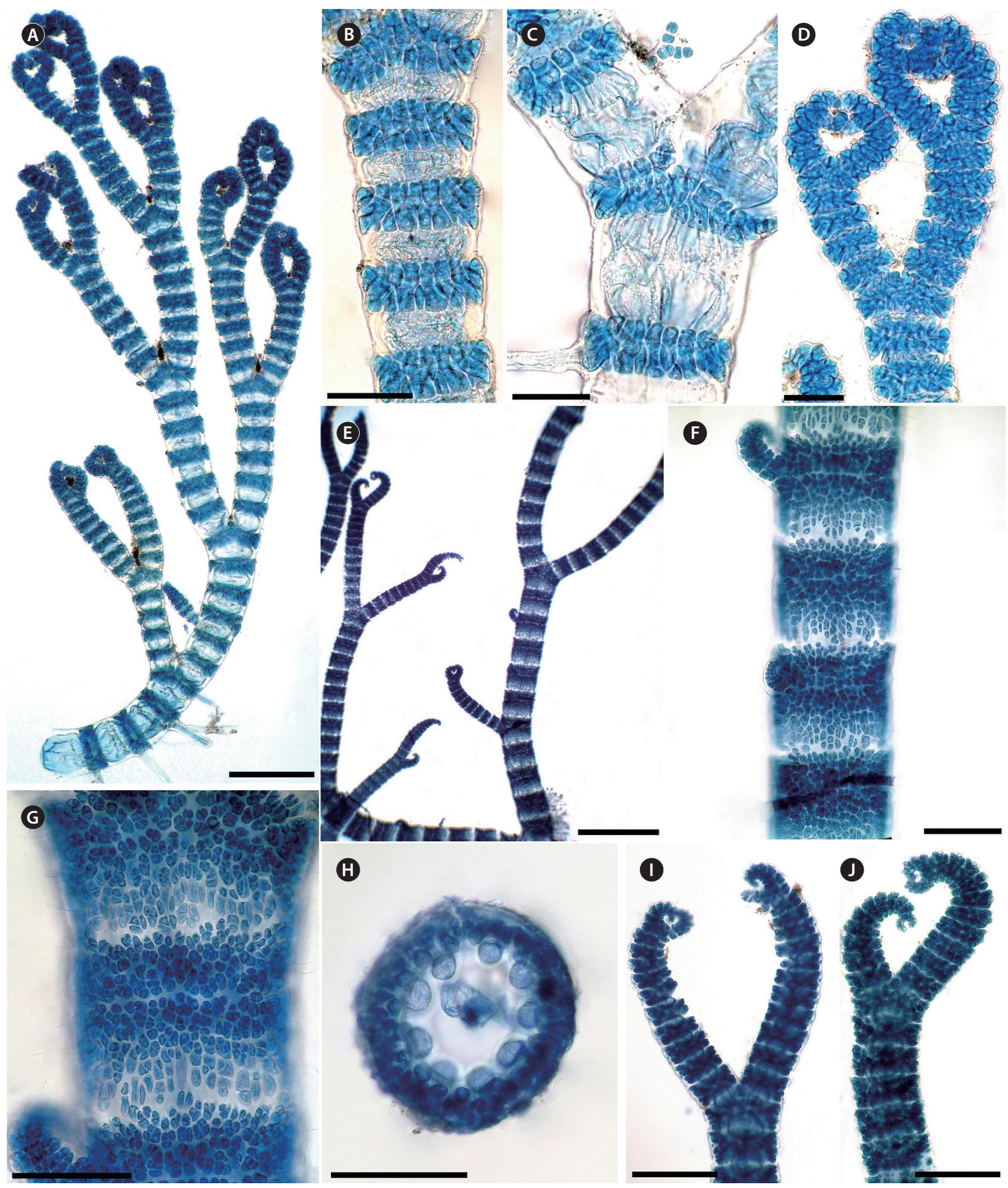

Fig. 8. (A-D) Ceramium tenerrimum. (A) Habit. (B \& C) Details of cortication of nodes. (D) Detail of strongly inrolled apices. (E-J) C. circinatum. (E) Habit. ( $F \&$ G) Detail of cortication of nodes showing extensive cortex developed in basipetal direction. (H) Detail of the periaxial cells in crosssectional view of a node. (I \& J) Thalli with incurved apices. Scale bars represent: A \& F-J, $200 \mu \mathrm{m}$; B-D, $50 \mu \mathrm{m}, \mathrm{E}, 1 \mathrm{~mm}$. [Colour figure can be viewed at http://www.e-algae.org]. 
2a. Thalli to $200 \mu \mathrm{m}$ in diameter; periaxial cells 5-6; branching at intervals of 7-9 on main axes, 10-14 on lateral axes; gland cells rarely develop from cortical cells of acropetally corticating filaments and are ovoid; tetrasporangia unilateral, usually only on adaxial side ------------- G. flaccida

2b. Thalli to $120 \mu \mathrm{m}$ in diameter; periaxial cells 6-7; branching at intervals of 3-4 on main axes, 4-6 on lateral axes; gland cells develop from cortical cells of acropetally developed filaments and are ovoid; tetrasporangia whorled, tetrahedrally divided

G. taylorii

In Morocco, G. mazoyerae was first reported as Ceramium gracillimum var. byssoideum by Dangeard (1949), which was considered by Cho et al. (2008) to be a taxonomic synonym of this taxon. This species is clearly distinguished from all Moroccan Gayliella by its acropetal corticating filaments 1-2 cells long, and only 1 basipetal horizontally elongate cell (Fig. 9A-G) and by its nodes consisting of 4 periaxial cells compared with the 5-6 and 6-7 periaxial cells in G. flaccida and G. taylorii, respectively (Cho et al. 2008). In forming four periaxial cells, one basipetal horizontally elongate cell and 1-2 cortical cells growing acropetally it shows similarity to G. transversalis (Collins et Hervey) T. O. Cho et Fredericq. However, in the latter species branching intervals are longer, 5-6 celled in main axes and 8-10 celled in the lateral axes, compared with the 4-5 and 4-6, respectively in G. mazoyerae (Fig. 9A-E).

Gayliella flaccida has been reported as Ceramium flaccidum from Morocco (Benhissoune et al. 2003). This species is similar to G. taylorii in the shape of the cortex because in both species the acropetal corticating filaments are 3-4 cells long, and the basipetal filament is 2-3 cells long (Fig. 10E-I). However, the first species displays an assemblage of characters that clearly distinguishes it from all other species of the genus. Only G. flaccida has thalli reaching $12 \mathrm{~cm}$ in height, and it is the only species that has 5-6 periaxial cells per segment and with internodes 8-12 times as long as broad, except in the upper part of the plant (Maggs and Hommersand 1993, Cho et al. 2008, Lagan and Trono 2017). The erect thalli in the other six species of the genus do not exceed $1.5 \mathrm{~cm}$ in height (Cho et al. 2008). In G. taylorii the thalli grow to lengths of no more than $1.2 \mathrm{~cm}$, with 6-7 periaxial cells per segment and with branching at intervals of 3-4 axial cells in the main axes and at intervals of 4-6 axial cells in lateral axes (Fig. 10A \& B). In addition, branches are indeterminate in G. flaccida, while in G. taylorii they are sometimes determinate (Cho et al. 2008).
Womersley (1978) placed Ceramium taylorii in synonymy with C. flaccidum, but South and Skelton (2000) maintained $C$. taylorii as a separate taxon. They examined isotype material of $C$. taylorii from Cabeza Ballena, Baja California, and noted that the nodal structure is quite different from that included under Ceramium flaccidum and concluded that the proposed synonymy of $C$. taylorii under C. flaccidum appears to be unwarranted. Gayliella flaccida and G. taylorii are collected from the two shores of Morocco, Atlantic and Mediterranean, while G. mazoyerae was reported only from the Atlantic side.

The present study is the first detailed description of the three species from Morocco. This is the first record of G. taylorii on the Moroccan Atlantic coast and one of the rare records of this species throughout the Atlantic Ocean.

\section{Centroceras}

As currently defined, the genus Centroceras Kützing contains 17 species (Guiry and Guiry 2018). Only one species has been reported from Morocco, the type species Centroceras clavulatum (C. Agardh) Montagne. C. clavulatum had been thought to have an almost cosmopolitan tropical-warm temperate distribution (Lüning 1990, van den Hoek and Breeman 1990). But several authors noted that the entire group is in need of a systematic revision (e.g., Athanasiadis 1996).

De Barros-Barreto et al. (2006) reported that C. clavulatum may consist of a species complex. Later, Won et al. (2009) pointed out that C. clavulatum has a biogeographic distribution limited to the Pacific Ocean based on comparative morphological and molecular analyses of specimens going under the name C. clavulatum worldwide, and according to those authors material going under the name C. clavulatum is often misidentified and in fact separable into nine discrete taxa based on the comparative development of the acropetal cortical filaments. Agreeing with Gallagher and Humm (1983) who reported the potential taxonomic value of the gland cells. Won et al. (2009) pointed out that the gland cells are more important than previously used as one of the key characters in Centroceras, and they described two different types of gland cells by their shape: flattened or ovoid. Centroceras gasparrinii has ovoid gland cells (Fig. $11 \mathrm{H} \&$ I), whereas in C. clavulatum they are flattened. Furthermore, the numbers of periaxial cells per segment are up to 19 in Centroceras gasparrinii, while in C. clavulatum they are 13-16 (De Barros-Barreto et al. 2006, Won et al. 2009, 2010, Schneider et al. 2015). 

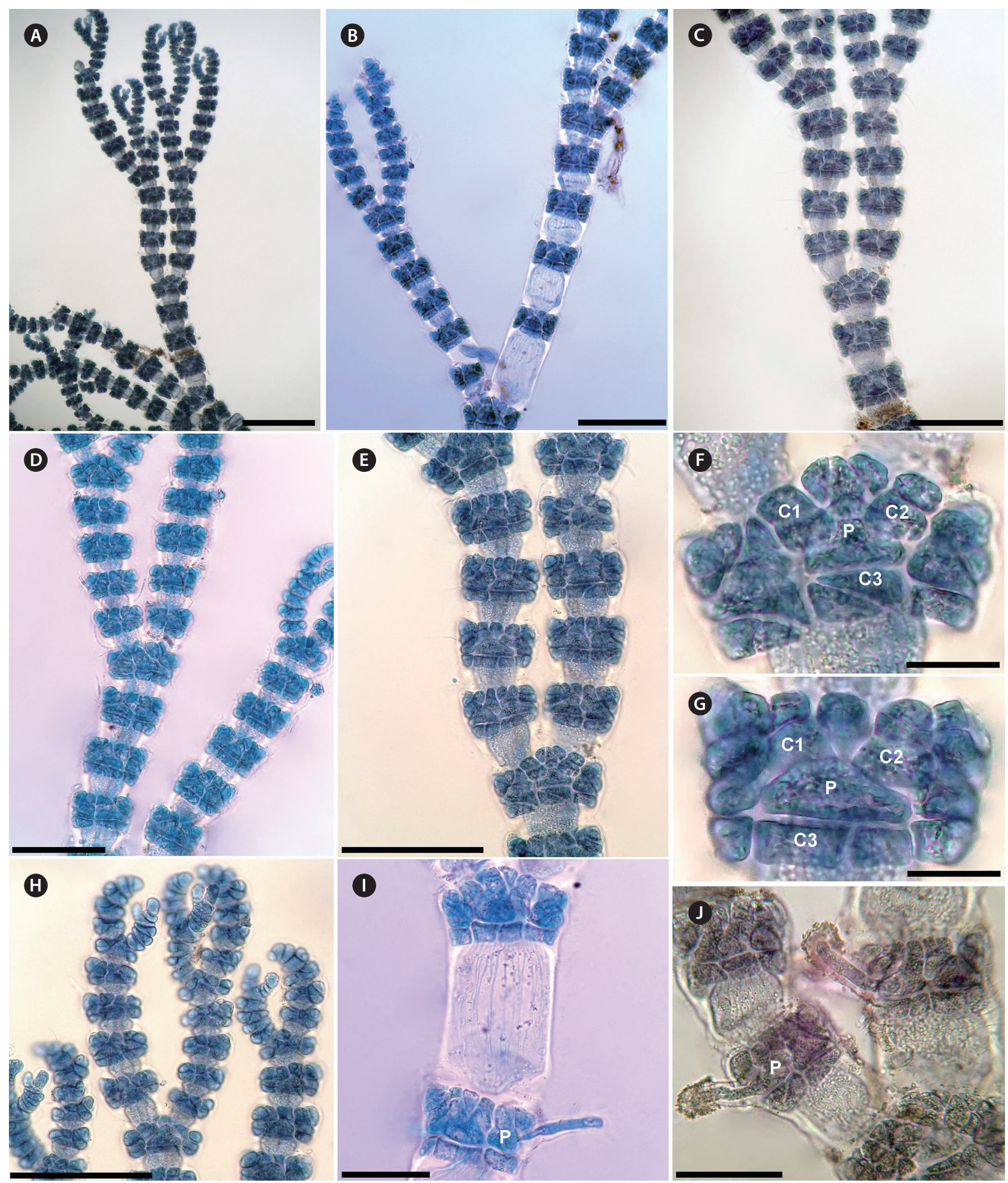

Fig. 9. Gayliella mazoyerae. (A) Habit. (B-E) Erect part showing branching pattern and interval of branching. (F \& G) Detail of the cortication of nodes showing a periaxial cell (p) and two acropetal cortical initials (c1-c2) and one basipetal-horizontal cortical initial (c3). (H) Apical region. (I \& J) Unicelluar rhizoids issued from periaxial cell (p). c1-3, cortical initials, numbered by sequence of formation. Scale bars represent: A-E \& H, $100 \mu \mathrm{m}$; F \& G, $20 \mu \mathrm{m}$; I J, $40 \mu \mathrm{m}$. [Colour figure can be viewed at http://www.e-algae.org]. 


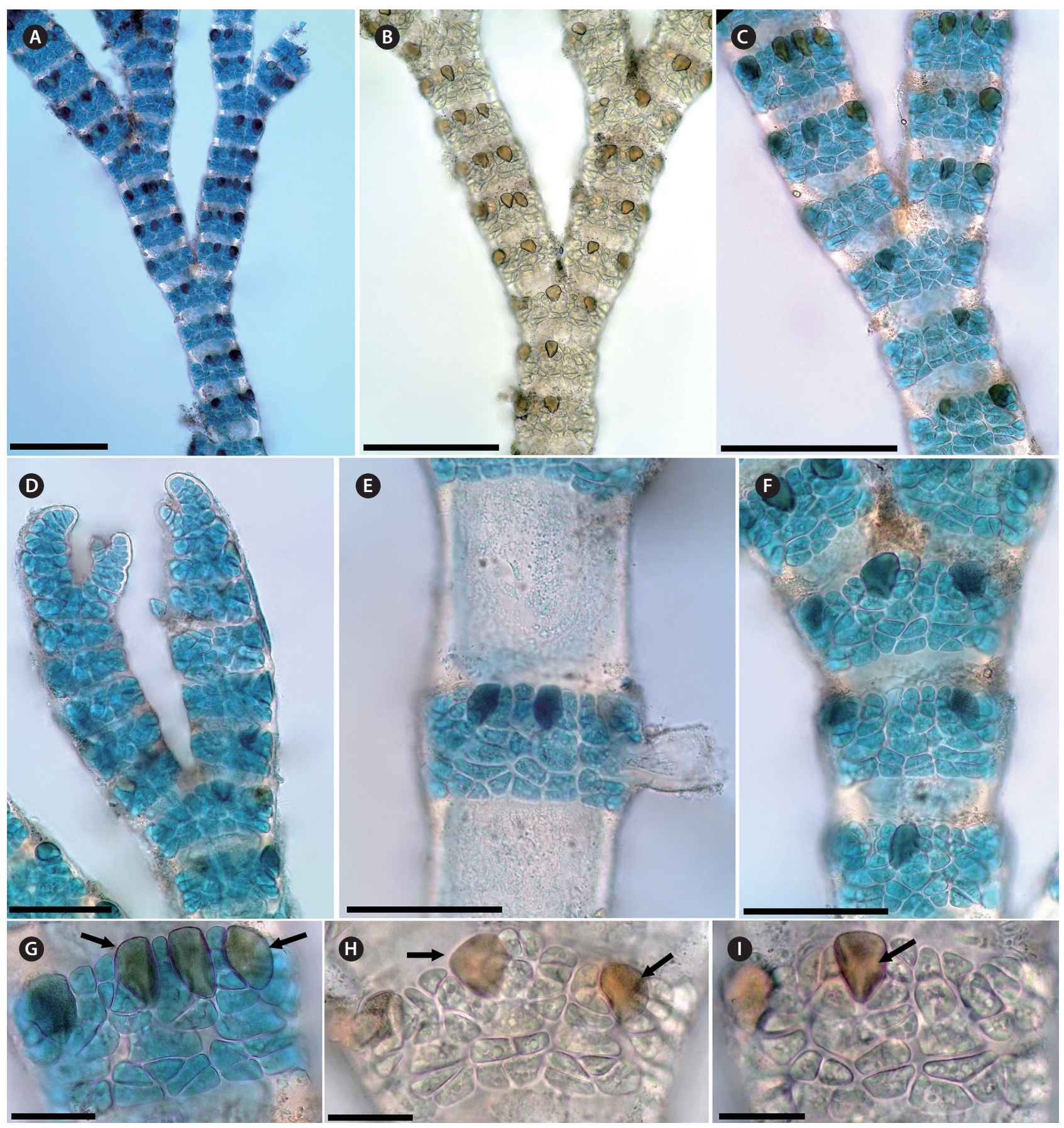

Fig. 10. Gayliella taylorii. (A-C) Thallus showing branching pattern and interval of branching. (D) Apical region. (E) Unicellular rhizoid issued from periaxial cell. (F-I) Detail of mature corticated nodes showing 3-4 cortical cells growing acropetally, 2-3 cortical cells growing basipetally and gland cells (arrows) developing from cortical cells of acropetally corticating filaments. Scale bars represent: A-C, $200 \mu \mathrm{m} ; \mathrm{D}-\mathrm{F}, 100 \mu \mathrm{m} ; \mathrm{G}-\mathrm{I}, 30 \mu \mathrm{m}$. [Colour figure can be viewed at http://www.e-algae.org]. 


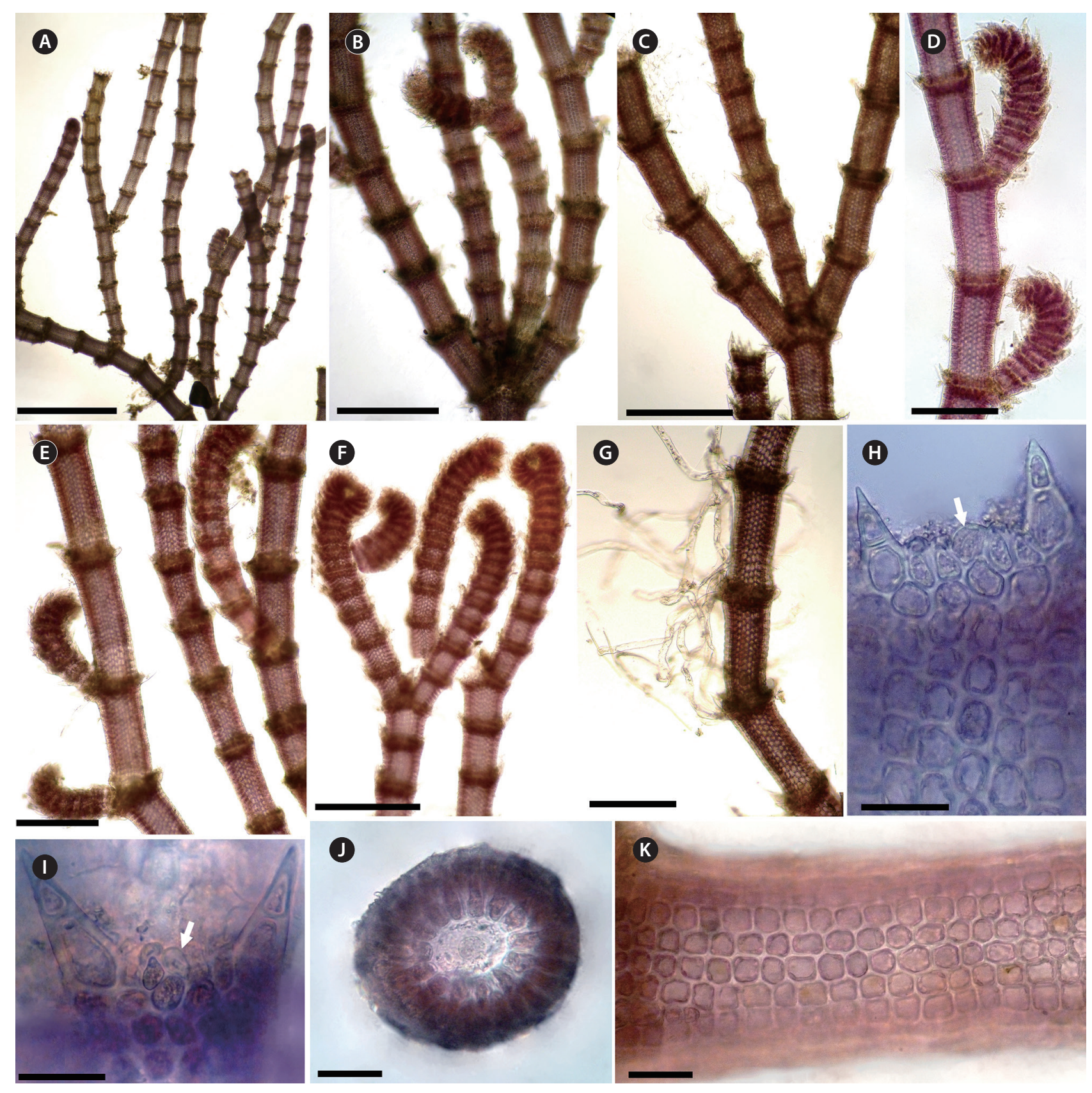

Fig. 11. Centroceras gasparrinii. (A) Habit of the lower part of a thallus. (B \& C) Tetrachotomous (B) or trichotomous (C) branches at branching points (arrows). (D \& E) Adventitious branchlets arranged on abaxial sides of dichotomous axes. (F) Apical region. (G) Lower part of thallus showing rhizoids produced from periaxial cells. (H \& I) Mature cortication showing cortical filaments with gland cells (arrows). (J) Cross section of axis showing 14 periaxial cells. (K) Detail of cortical cells on surface view. Scale bars represent: A, 1 mm; B-G, $300 \mu$ m; I-K, $30 \mu \mathrm{m}$. [Colour figure can be viewed at http://www.e-algae.org]. 
Centroceras specimens with a dichotomous habit from Morocco have been recognized as C. clavulatum. It has been reported from all coasts of Morocco, after the first record of this species was made from the Mediterranean coast of Morocco by Bornet (1892). It has been known as a very common species in the Moroccan marine flora. However, the results in this study show that all Centroceras collections with dichotomous branching patterns from Moroccan coasts are not C. clavulatum but C. gasparrinii.

Centroceras gasparrinii is similar to C. clavulatum in having a dichotomous branching pattern, straight spines, ovoid terminal acropetal cortical cells and in the arrangement of cortical filaments (Fig. 11). However, the branching in C. gasparrinii is sometimes tri- to tetrachotomous by the production of additional branches from the nodal region of a branching point (Fig. 11B \& C). The adventitious branches that arise from periaxial cells are short, usually inrolled toward the axis and arranged on the abaxial side of the dichotomous axis (Fig. 11D \& E). Furthermore, in C. gasparrinii the ovoid shape of the gland cell clearly separates it from C. clavulatum.

C. gasparrinii is recognizable by the combination of the following characters: terminal acropetal cortical cells ovoid; gland cell ovoid; axial cells with 12 to 19 periaxial cells; branching is pseudodichotomous to trichotomous and, rarely tetrachotomous, at intervals of 10-13 axial cells; spines straight, whorled at each node; tetrasporangia covered, with involucral branchlets (Fig. 11). In light of our study, C. clavulatum is excluded from the Moroccan flora, and C. gasparrinii is now recognized instead of C. clavulatum.

\section{Corallophila}

The generic concept of Corallophila was revised by Norris (1993) and later by Cho et al. (2000). According to Cho et al. (2000) Corallophila is intermediate between Ceramium and Centroceras in some features, but the genus is distinctive in having tetrasporangia in stichidia, almost completely embedded in the cortex. Cystocarps naked, without involucral branches, spermatangia that occur on outer cortical cells, rhizoids formed from periaxial to inner cortical cells, rectangular cortical cells that are regularly arranged in longitudinal rows and grow basipetally. Norris (1993) identified that the development of spermatangia on the cortical cells and tetrasporangia being mostly covered by outer cortical cells as key characters for Corallophila. In most species of Corallophila, each periaxial cell cuts off four cortical initials that devel- op the cortical filaments, in which two acropetal initials are cut off from the anterior end of a periaxial cell and two basipetal initials are cut off from the posterior end (Norris 1993).

Despite the fact that Cho et al. (2000) confirmed the generic concept of Corallophila proposed by Norris (1993) and that others have recognized the genus (e.g., Abbott 1999), the distinctiveness of the genus Corallophila is controversial. Ten species of Corallophila are currently recognized worldwide (Guiry and Guiry 2018). Only one species, Corallophila cinnabarina (Grateloup ex Bory) R. E. Norris, is recognized in Morocco.

C. cinnabarina is recognizable by the combination of the following characters: plants $1-4 \mathrm{~cm}$ tall; prostrate, may also produce an extensive pseudodichotomously branched upright system; forcipate tips; pericentral cells 6 , sometimes 7 or 8 ; two acropetal and two basipetal corticating filaments on each pericentral cell, with the latter longer and forming rows of rectangular corticating cells with long axes perpendicular to the thallus axis, cortical cells broader than long and arranged in regular files, tetrasporangia immersed.

C. cinnabarina was not found during the present study. It has been reported only in one reference by GonzálezGarcía and Conde-Poyales (1994), without illustrations and / or descriptions.

\section{Microcladia}

The morphological characters of Microcladia are somewhat related to those of Ceramium. In the above genera, the periaxial cells are produced in a rhodomelacean sequence and lateral branches originate from the apical cell, whereas in the more primitive genera Carpoblepharis and Reinboldiella the periaxial cells are produced in opposite pairs, and the indeterminate branches originate from periaxial cell. Since certain $\mathrm{Ce}$ ramium are completely corticated, as in Microcladia, several authors have found it difficult to differentiate the two genera. However, Hommersand (1963) distinguished species of Microcladia from fully corticated species of Ceramium in having thalli producing secondary cortical cells in an acropetal direction only (producing secondary cortical cells in both an acropetal and basipetal direction in Ceramium).

The genus Microcladia includes 10 species worldwide (Guiry and Guiry 2018). Most of them are distributed on Pacific coasts. It is one of the most geographically limited genera known, with four endemics species (Silva et al. 1996, Guiry and Guiry 2018). The type species Micro- 
cladia glandulosa is the most widely distributed species and the only species of the genus currently recognized from Morocco (Benhissoune et al. 2003), although most of these references for Morocco that cite this species are without illustrations and / or descriptions.

Microcladia glandulosa is distinguished from other species in the genus by the following combination of characteristics: fronds tufted, $2-10 \mathrm{~cm}$ high, with prostrate axes that give rise to numerous erect axes; branching is regularly in an alternate or pseudodichotomous, at intervals of 6-10 axial cells, at an angle of $30-60^{\circ}$; abundant angular gland cells; periaxial cells $6-8$ of unequal size, the first abaxial and the last adaxial; tetrasporangia in upper branchlets, unilateral, abaxial, singly or in pairs from the side of the first periaxial cells, immersed; cystocarps sessile on abaxial on outer edges of upper branches, enclosed by 2-3 involucral branchlets.

The abundant gland cells of $M$. glandulosa are a very conspicuous feature. Gland cells are also present in the South African Microcladia exserta M. J. Wynne, as described by Wynne (1985). But the gland cells in the type of the genus are less numerous and smaller than the cortical cells. In terms of their high number and conspicuousness, the gland cells in $M$. exserta seem to be the most highly developed of any member in the tribe Ceramieae (Wynne 1985).

\section{CONCLUSION}

This research was undertaken to document species richness of the tribe Ceramieae in Morocco. In this regard, it was successful insofar as it increased the number of taxa recognized from 22 to 27. Ceramium is the most represented genus in the tribe, by 21 species and varieties, in which 3 are reported for the first time from Morocco: Ceramium botryocarpum, also reported for the first time outside the northeastern Atlantic coast of Europe, $C$. cingulatum and C. echionotum var. mediterraneum. The latter variety is widely distributed in the Mediterranean Sea. Our report of this variety from the Atlantic coast of Morocco is one of the rare records from outside the Mediterranean. The presence of Ceramium ciliatum var. robustum and Ceramium codii are confirmed, which was previously doubtful. The occurrence of five previously reported taxa (Ceramium callipterum, C. deslongchampii, C. giacconei, C. virgatum var. implexocontortum, and $C$. siliquosum var. lophophorum) could not be confirmed.

All specimens of Centroceras examined in this study are not Centroceras clavulatum but Centroceras gaspar- rini. As a result, C. clavulatum is excluded from Moroccan flora and replaced with C. gasparrinii.

The presence of the genus Gayliella is confirmed and three species are listed of which G. taylorii is newly added from Morocco, and G. mazoyerae is reported and illustrated for the first time after the only record of this species was made by Dangeard (1949) as Ceramium gracillimum var. byssoideum. The presence of Microcladia and especially Corallophila in Morocco requires special attention in future investigations.

Not all of our collected specimens have been identified in this study because many of them could not be clearly characterized due to lacking critical features. This study showcases the need for more phycological studies in order to clarify the Moroccan algal biodiversity, particularly in difficult-to-reach or inaccessible areas that remain poorly known.

\section{SUPPLEMENTARY MATERIAL}

Supplementary Table S1. Collection data for specimens of the Ceramieae examined in this study (http://ealgae.org).

\section{REFERENCES}

Abbott, I. A. 1999. Marine red algae of the Hawaiian Islands. Bishop Museum Press, Honolulu, HI, 477 pp.

Agardh, C. A. 1811 [1810-1812]. Dispositio algarum Sueciae. Litteris Berlingianis, Lundae [Lund], pp. 17-26.

Anderson, R. J. \& Stegenga, H. 1989. Subtidal algal communities at Bird Island, Eastern Cape, South Africa. Bot. Mar. 32:299-311.

Athanasiadis, A. 1996. Morphology and classification of the Ceramioideae (Rhodophyta) based on phylogenetic principles. Opera Bot. 128:5-216.

Ballantine, D. L. 1990. Ceramium bisporum (Rhodophyta, Ceramiales), an unusual new species from deep-water habitats in the Caribbean. Phycologia 29:146-149.

Benhissoune, S., Boudouresque, C.-F., Perret-Boudouresque, M. \& Verlaque, M. 2003. A checklist of the seaweeds of the Mediterranean and Atlantic coasts of Morocco. IV. Rhodophyceae-Ceramiales. Bot. Mar. 46:55-68.

Boo, S. M. \& Lee, I. K. 1985. A taxonomic reappraisal of Ceramium fastigiatum Harvey (Rhodophyta, Ceramiaceae). Korean J. Bot. 28:217-224.

Boo, S. M. \& Lee, I. K. 1994. Ceramium and Campylaephora (Ceramiaceae, Rhodophyta). In Akatsuka, I. (Ed.) Biol- 
ogy of Economic Algae. SPB Academic Publishing, The Hague, pp. 1-33.

Boo, S. M. \& Yoon, H. S. 1993. Systematic studies of Ceramium kondoi (Ceramiaceae, Rhodophyta) in the field and in culture. Korean J. Phycol. 8:179-189.

Bornet, É. 1892. Les algues de P.-K.-A. Schousboe: récoltées au Maroc \& dans la Méditerranée de 1815 à 1829. Mém. Soc. Sci. Nat. Math. Cherbourg 28:165-378.

Cho, T. O., Boo, S. M., Hommersand, M. H., Maggs, C. A., McIvor, L. \& Fredericq, S. 2008. Gayliella gen. nov. in the tribe Ceramieae (Ceramiaceae, Rhodophyta) based on molecular and morphological evidence. J. Phycol. 44:721-738.

Cho, T. O., Choi, H.-G., Hansen, G. \& Boo, S. M. 2000. Corallophila eatoniana comb. nov. (Ceramiaceae, Rhodophyta) from the Pacific coast of North America. Phycologia 39:323-331.

Cho, T. O. \& Fredericq, S. 2006. Two creeping Ceramium species (Ceramiaceae, Rhodophyta) from the Florida Keys: C. reptans sp. nov. and recircumscription of $C$. codii (Richards) Mazoyer. Phycologia 45:495-504.

Cho, T. O. \& Riosmena-Rodriguez, R. 2008. Ceramium periconicum sp. nov. (Ceramiaceae, Rhodophyta): a new subtidal species from Baja California Sur, Mexico. Bot. Mar. 51:307-312.

Cho, T. O., Riosmena-Rodriguez, R. \& Boo, S. M. 2003. First record of Ceramium giacconei (Ceramiaceae, Rhodophyta) in the North Pacific: developmental morphology of vegetative and reproductive structures. Bot. Mar. 46:548-554.

Coppejans, E. 1977. Végétation marine de l'île de Port-Cros (Parc National). XV. Ceramium cingulatum Weber van Bosse nouvelle pour la Méditerranée, et quelques populations d'un Ceramium sp. à parasporocystes. Bio. Jaarb. Dodonaea 45:51-61.

Coppejans, E. 1983. Iconographie d'algues méditerranéenes: Chlorophyta, Phaeophyta, Rhodophyta. Bibliotheca Phycol. 63. J. Cramer, Vaduz, 574 pp.

Coppejans, E. \& Boudouresque, C. F. 1981. Végétation marine de l'île de Port-Cros (Parc national). XXII. Sur quelques Ceramiaceae (Rhodophyta). Trav. Sci. Parc Natl. PortCros 7:85-101.

Cormaci, M. \& Furnari, G. 1991. The distinction of Ceramium giacconei sp. nov. (Ceramiales, Rhodophyta) in the Mediterranean Sea from Ceramium cingulatum. Cryptogam. Algol. 12:45-53.

Dangeard, P. 1949. Les algues marines de la côte occidentale du Maroc. Botaniste 34:89-189.

De Barros-Barreto, M. B., McIvor, L., Maggs, C. A. \& Ferreira, P. C. G. 2006. Molecular systematics of Ceramium and
Centroceras (Ceramiaceae, Rhodophyta) from Brazil. J. Phycol. 42:905-921.

Dixon, P. S. 1960. Studies on marine algae of the British Isles: Ceramium shuttleworthianum (Kütz.) Silva. J. Mar. Biol. Assoc. U. K. 39:375-390.

Feldmann-Mazoyer, G. 1941['1940']. Researches sur les Cêramiacées de la Méditerranée. Imprimerie Minerva, Algiers, $510 \mathrm{pp}$.

Gallagher, S. B. \& Humm, H. J. 1983. Centroceras internitens n. sp. (Rhodophyceae, Ceramiaceae) from the western tropical North Atlantic Ocean. J. Phycol. 19:261-268.

Gómez Garreta, A., Gallardo, T., Ribera, M. A., Cormaci, M., Furnari, G., Giaccone, G. \& Boudouresque, C. F. 2001. Checklist of Mediterranean seaweeds. III. Rhodophyceae Rabenh. 1. Ceramiales Oltm. Bot. Mar. 44:425-460.

González-García, J. A. \& Conde-Poyales, F. 1991. Estudio florístico, fenológico, autoecológico y fitogeográfico del macrofitobentos de la Mar Chica (Sebcha Buareg de Nador, Mediterráneo Marroquí). Acta Bot. Malacit. 16:6380.

González-García, J. A. \& Conde-Poyales, F. 1994. Catálogo del macrofitobentos del Mediterráneo de Marruecos. Acta Bot. Malacit. 19:5-27.

Greuter, W., McNeill, J., Barrie, F. R., Burdet, H. M., Demoulin, V., Filgueiras, T. S., Nicolson, D. H., Silva, P. C., Skog, J. E., Trehane, P., Turland, N. J. \& Hawksworth, D. L. 2000. International Code of Botanical Nomenclature (St Louis Code). Adopted by the Sixteenth International Botanical Congress, St. Louis, Missouri, July-August 1999. Koeltz Sci. Books, Königstein, 474 pp.

Greville, R. K. 1830. Algae Britannicae. MacLachlan \& Stewart, Edinburgh, $218 \mathrm{pp}$.

Guiry, M. D. \& Guiry, G. M. 2018. AlgaeBase. World-wide electronic publication, National University of Ireland, Galway. Available from: http://www.algaebase.org. Accessed Apr 21, 2018.

Hassoun, M., Salhi, G., Moussa, H., Riadi, H., Kazzaz, M. \& Zbakh, H. 2016. Ceramium cornutum and Ceramium pallidum (Rhodophyta: Ceramiales) two new records for Morocco: morphology and reproductive structures. Bot. Lett. 163:25-31.

Hommersand, M. H. 1963. The morphology and classification of some Ceramiaceae and Rhodomelaceae. Univ. Calif. Publ. Bot. 35:165-366.

Index Nominum Algarum. 2018. University Herbarium, University of California, Berkeley. Compiled by Paul Silva. Available from: http://ucjeps.berkeley.edu/CPD/. Accessed Apr 21, 2018.

Itono, H. 1972. The genus Ceramium (Ceramiaceae, Rhodophyta) in southern Japan. Bot. Mar. 15:74-86. 
Kazzaz, M. \& Riadi, H. 2000. Inventaire préliminaire de la phycoflore benthique du littoral marocain. II. Rhodophyceae. Acta Bot. Barc. 46:53-88.

Kützing, F. T. 1849. Species algarum. F. A. Brockhaus, Lipsiae [Leipzig], $922 \mathrm{pp}$.

Kylin, H. 1907. Studien über die Algenflora der schwedischen Westküste. Akademische Abhandlung. K. W. Appelbergs Buchdruckeri, Uppsala, 287 pp.

Lagan, E. J. C. \& Trono, G. C. Jr. 2017. Notes on Ceramium Roth and Gayliella TO Cho, LJ McIvor et SM Boo (Rhodophyta, Ceramiaceae) from the Philippines. Philip. Sci. Lett. 10:38-49.

Lamarck, J. B. \& De Candolle, A. P. 1805. Flore française. Troisième édition. Vol. 2. Paris, 568 pp.

Lüning, K. 1990. Seaweeds: their environment, biogeography, and ecophysiology. 2nd ed. John Wiley \& Sons, New York, $527 \mathrm{pp}$.

Maggs, C. A. \& Hommersand, M. H. 1993. Seaweeds of the British Isles. Vol. 1. Rhodophyta Part A, 3. Ceramiales. HMSO, London, $444 \mathrm{pp}$.

Maggs, C. A., Ward, B. A., McIvor, L. M., Evans, C. M., Rueness, J. \& Stanhope, M. J. 2002. Molecular analyses elucidate the taxonomy of fully corticated, nonspiny species of Ceramium (Ceramiaceae, Rhodophyta) in the British Isles. Phycologia 41:409-420.

Mazoyer, G. 1938a. Les Ceramiées de l'Afrique du Nord. Bull. Soc. Hist. Nat. Afr. Nord. 29:317-331.

Mazoyer, G. 1938b. Sur une nouvelle espèce de Ceramium des côtes Marocaines: Ceramium callipterum nov. sp. Bull. Soc. Hist. Nat. Afr. Nord. 29:14-18.

Millar, A. J. K. 2002. Ceramium juliae (Ceramiaceae, Ceramiales), a new red algal species with distinctive spines from eastern Australia. Aust. Syst. Bot. 15:493-500.

Nakamura, Y. 1965. Species of the genera Ceramium and Campylaephora, especially those of northern Japan. Sci. Pap. Inst. Algol. Res. Fac. Sci. Hokkaido Univ. 5:119-180.

Norris, J. N. 2014. Marine algae of the northern Gulf of California II: Rhodophyta. Smithsonian Contributions to Botany, No. 96. Smithsonian Institution Scholarly Press, Washington, DC, 555 pp.

Norris, R. E. 1993. Taxonomic studies on Ceramieae (Ceramiales, Rhodophyta) with predominantly basipetal growth of corticating filaments. Bot. Mar. 36:389-398.

Nunes, J. D. C., Barros-Barreto, M. B. \& Guimarães, S. M. P. B. 2008. A família Ceramiaceae (Ceramiales, Rhodophyta) no estado da Bahia, Brasil. Monografías Ficol. 3:75-159.

N'Yeurt, A. D. R. \& Payri, C. E. 2010. Marine algal flora of French Polynesia III. Rhodophyta, with additions to the Phaeophyceae and Chlorophyta. Cryptogam. Algol. 31:3-205.
Richards, H. M. 1901. Ceramothamnion codii, a new Rhodophyceous alga. Bull. Torrey Bot. Club 28:257-265.

Rodríguez-Prieto, C., Ballesteros, E., Boisset, F. \& AfonsoCarrillo, J. 2013. Guía de las macroalgas y fanerógamas marinas del Mediterráneo occidental. Ediciones Omega, Barcelona, $656 \mathrm{pp}$.

Sansón, M. 1994. Notes on Ceramiaceae (Rhodophyta) from the Canary Islands: new records and observations on morphology and geographical distribution. Bot. Mar. 37:347-356.

Schneider, C. W., Cianciola, E. N., Popolizio, T. R., Spagnuolo, D. S. \& Lane, C. E. 2015. A molecular-assisted alpha taxonomic study of the genus Centroceras (Ceramiaceae, Rhodophyta) in Bermuda reveals two novel species. Algae 30:15-33.

Secilla, A. 2012. La familia Ceramiaceae sensu lato en la costa de Bizkaia. Guineana 18:1-369.

Serio, D., Catra, M., Collodoro, D. \& Nisi, A. 2011. Ceramium cormacii sp. nov. (Ceramiaceae, Rhodophyta), a new Mediterranean species epizoic on loggerhead sea turtles (Caretta caretta). Bot. Mar. 54:545-550.

Silva, P. C., Basson, P. W. \& Moe, R. L. 1996. Catalogue of the benthic marine algae of the Indian Ocean. Univ. Calif. Publ. Bot. 79:1-1259.

Simons, R. H. 1966. The genus Ceramium in South Africa. Bothalia 9:153-156

Skage, M., Gabrielsen, T. M. \& Rueness, J. 2005. A molecular approach to investigate the phylogenetic basis of three widely used species groups in the red algal genus Ceramium (Ceramiales, Rhodophyta). Phycologia 44:353360.

South, G. R. \& Skelton, P. A. 2000. A review of Ceramium (Rhodophyceae, Ceramiales) from Fiji and Samoa, South Pacific. Micronesica 33:45-98.

van den Hoek, C. \& Breeman, A. M. 1990. Seaweed biogeography of the north Atlantic: where are we now? In Garbary, D. J. \& South, G. R. (Eds.) Evolutionary Biogeography of the Marine Algae of the North Atlantic. Springer-Verlag, Berlin, pp. 55-86.

Weber van Bosse, A. 1923. Liste des Algues du Siboga, III: Rhodophyceae. Seconde partie: Ceramiales. SibogaExped. Monogr. 59c:311-392.

Wolf, M. A., Sciuto, K., Maggs, C. A., de Barros-Barreto, M. B. B., Andreoli, C. \& Moro, I. 2011. Ceramium Roth (Ceramiales, Rhodophyta) from Venice lagoon (Adriatic Sea, Italy): comparative studies of Mediterranean and Atlantic taxa. Taxon 60:1584-1595.

Womersley, H. B. S. 1978. Southern Australian species of Ceramium Roth (Rhodophyta). Mar. Freshw. Res. 29:205257. 
Womersley, H. B. S. 1998. The marine benthic flora of southern Australia, Rhodophyta: Part IIIC: Ceramiales-Ceremiaceae, Dasyaceae. Australian Biological Resources Study \& State Herbarium of South Australia, Canberra \& Adelaide, $535 \mathrm{pp}$.

Won, B. Y., Cho, T. O. \& Fredericq, S. 2009. Morphological and molecular characterization of species of the genus Centroceras (Ceramiaceae, Ceramiales), including two new species. J. Phycol. 45:227-250.

Won, B. Y., Fredericq, S. \& Cho, T. O. 2010. Two new species of Centroceras (Ceramiaceae, Rhodophyta) from KwaZuluNatal, South Africa. Eur. J. Phycol. 45:240-246.

Wynne, M. J. 1985. Microcladia exserta sp. nov. (Ceramiaceae, Rhodophyta) from the east coast of South Africa. Br. Phycol. J. 20:193-200. 